OPEN ACCESS

Edited by:

Xavier Mayali,

Lawrence Livermore National

Laboratory, USA

Reviewed by:

Song Xue,

Dalian University of Technology, China

Daniel Jonathan Sher,

University of Haifa, Israel

*Correspondence: Andrew E. Allen aallen@ucsd.edu

Specialty section: This article was submitted to

Aquatic Microbiology,

a section of the journal

Frontiers in Microbiology

Received: 01 April 2016

Accepted: 25 May 2016

Published: 09 June 2016

Citation:

Diner RE, Schwenck SM, McCrow JP, Zheng $H$ and Allen AE (2016) Genetic

Manipulation of Competition for Nitrate between Heterotrophic Bacteria and Diatoms. Front. Microbiol. 7:880. doi: 10.3389/fmicb.2016.00880

\section{Genetic Manipulation of Competition for Nitrate between Heterotrophic Bacteria and Diatoms}

\author{
Rachel E. Diner ${ }^{1,2}$, Sarah M. Schwenck ${ }^{1,2}$, John P. McCrow ${ }^{2}$, Hong Zheng ${ }^{2}$ and \\ Andrew E. Allen ${ }^{1,2 *}$
}

1 Integrative Oceanography Division, Scripps Institution of Oceanography, University of California San Diego, La Jolla, CA, USA, ${ }^{2}$ Microbial and Environmental Genomics Group, J. Craig Venter Institute, La Jolla, CA, USA

Diatoms are a dominant group of eukaryotic phytoplankton that contribute substantially to global primary production and the cycling of important elements such as carbon and nitrogen. Heterotrophic bacteria, including members of the gammaproteobacteria, are commonly associated with diatom populations and may rely on them for organic carbon while potentially competing with them for other essential nutrients. Considering that bacterioplankton drive oceanic release of $\mathrm{CO}_{2}$ (i.e., bacterial respiration) while diatoms drive ocean carbon sequestration vial the biological pump, the outcome of such competition could influence the direction and magnitude of carbon flux in the upper ocean. Nitrate availability is commonly a determining factor for the growth of diatom populations, particularly in coastal and upwelling regions. Diatoms as well as many bacterial species can utilize nitrate, however the ability of bacteria to compete for nitrate may be hindered by carbon limitation. Here we have developed a genetically tractable model system using the pennate diatom Phaeodactylum tricornutum and the widespread heterotrophic bacteria Alteromonas macleodii to examine carbon-nitrogen dynamics. While subsisting solely on $P$. tricornutum derived carbon, $A$. macleodii does not appear to be an effective competitor for nitrate, and may in fact benefit the diatom; particularly in stationary phase. However, allochthonous dissolved organic carbon addition in the form of pyruvate triggers $A$. macleodii proliferation and nitrate uptake, leading to reduced $P$. tricornutum growth. Nitrate reductase deficient mutants of $A$. macleodii $(\triangle$ nas $A)$ do not exhibit such explosive growth and associated competitive ability in response to allochthonous carbon when nitrate is the sole nitrogen source, but could survive by utilizing solely P. tricornutum-derived nitrogen. Furthermore, allocthonous carbon addition enables wild-type $A$. macleodii to rescue nitrate reductase deficient $P$. tricornutum populations from nitrogen starvation, and RNA-seq transcriptomic evidence supports nitrogen-based interactions between diatoms and bacteria at the molecular level. This study provides key insights into the roles of carbon and nitrogen in phytoplankton-bacteria dynamics and lays the foundation for developing a mechanistic understanding of these interactions using co-culturing and genetic manipulation.

Keywords: diatoms, bacteria, nitrate, competition, genetic manipulation, transcriptomics, Phaeodactylum, Alteromonas 


\section{INTRODUCTION}

Diatoms as well as bacteria are important drivers of oceanic biogeochemical cycling, and frequently occupy overlapping ecological niches. Diatoms are often the dominant primary producers in nutrient rich ecosystems, such as coastal upwelling regions, and can form dense and extensive blooms. Marine bacteria constitute the majority of oceanic biomass (Pomeroy, 1974; Fuhrman, 1989; Whitman et al., 1998), and heterotrophic bacteria utilize and rely on phytoplankton-derived organic matter for survival and growth (Azam and Malfatti, 2007; Sarmento and Gasol, 2012; Buchan et al., 2014). Diatoms and bacteria are subject to frequent environmental fluctuations in availability of essential nutrients such as nitrogen $(\mathrm{N})$ and carbon (C). Nitrate $\left(\mathrm{NO}_{3}^{-}\right)$in particular often reaches limiting concentrations during phytoplankton blooms (Falkowski and Oliver, 2007). Certain classes of heterotrophic bacteria, such as gammaproteobacteria, are consistently found in phytoplanktonassociated microbial communities, and may potentially compete with diatoms for scarce nutrients while simultaneously relying on them for organic C (Buchan et al., 2014). While population dynamics of phytoplankton and bacteria under different environmental conditions have been extensively examined, outside of a few recent studies (e.g., Durham et al., 2014; Amin et al., 2015; Smriga et al., 2016) relatively little is known regarding the cellular, metabolic, or genetic basis for different types of interactions (Bell and Mitchell, 1972; Amin et al., 2012). This is particularly true for competitive interactions (Amin et al., 2012). Laboratory model systems and new experimental approaches can enable hypothesis-testing and lead to new discoveries regarding interactions between diatoms and heterotrophic bacteria in productive microbial ecosystems and the associated influence on $\mathrm{C}$ and nutrient cycling.

A common regulator of primary productivity in marine ecosystems is availability of $\mathrm{NO}_{3}^{-}$. When estimating primary productivity and characterizing the magnitude of the biological pump it is assumed that inorganic $\mathrm{N}$ is converted into particulate organic matter entirely by phytoplankton (Dugdale and Goering, 1967; Bronk et al., 1994). Diatoms are excellent competitors for $\mathrm{NO}_{3}^{-}$, and have evolved efficient assimilation, storage and associated recycling systems (Serra et al., 1978; Dortch, 1990; Lomas and Gilbert, 2000; Allen et al., 2006, 2011). The emerging laboratory model diatom Phaeodactylum tricornutum has been used in many studies to investigate diatom $\mathrm{N}$ utilization, as well as responses to many other environmental variables such as iron $(\mathrm{Fe})$ and phosphorus (P) (Yongmanitchai and Ward, 1991; Geider et al., 1993; Allen et al., 2008; Jiao et al., 2011; Matthijs et al., 2015; Morrissey et al., 2015). These studies have been facilitated by development of a variety of tools for genetic manipulation in P. tricornutum (Siaut et al., 2007; Karas et al., 2015; Weyman et al., 2015; Nymark et al., 2016). Notably, mutant strains of $P$. tricornutum that are deficient in ability to utilize $\mathrm{NO}_{3}^{-}$have been crucial for understanding $\mathrm{N}$ uptake and storage, and impacts on cellular physiology (Levitan et al., 2014). The sequencing of the P. tricornutum genome (Bowler et al., 2008) revealed that about $6 \%$ of $P$. tricornutum genes appear to be bacterial in origin, including a $\mathrm{NAD}(\mathrm{P}) \mathrm{H}$ dependent assimilatory $\mathrm{NO}_{2}^{-}$, reductase, and are possibly the result of horizontal gene transfer. This suggests a historically intimate relationship between diatoms and bacteria, which might also have significant evolutionary implications.

Heterotrophic bacteria also play a large role in $\mathrm{N}$ cycling and remineralization (Zehr and Ward, 2002; Azam and Malfatti, 2007). They are known to utilize a variety of sources for satisfying their $\mathrm{N}$ requirements, including ammonium $\left(\mathrm{NH}_{4}^{+}\right)$, $\mathrm{NO}_{3}^{-}$, urea, free amino acids, and various other organic $\mathrm{N}$ compounds. In some studies, $\mathrm{NH}_{4}^{+}$and organic $\mathrm{N}$ sources such as amino acids have been shown to satisfy the bulk of heterotrophic bacterial $\mathrm{N}$ demand, while other organic $\mathrm{N}$ sources and inorganic $\mathrm{N}$ such as $\mathrm{NO}_{3}^{-}$appeared to play a more minor role (Wheeler and Kirchman, 1986; Keil and Kirchman, 1991). However, a large number of heterotrophic bacteria possess pathways for utilizing $\mathrm{NO}_{3}^{-}$and are able to grow using $\mathrm{NO}_{3}^{-}$ as a sole $\mathrm{N}$ source. Studies examining the molecular ecology of heterotrophic bacterial nitrate reductase genes (nasA) and their functionality have suggested that bacterial $\mathrm{NO}_{3}^{-}$utilization is globally widespread and may play an important role in inorganic $\mathrm{N}$ cycling in several ecosystems (Allen et al., 2001; Jiang et al., 2015). Further, heterotrophic bacteria have been shown to satisfy between 10 and $50 \%$ of their total $\mathrm{N}$ demand with dissolved inorganic nitrogen $\left(\mathrm{NH}_{4}^{+}\right.$and $\left.\mathrm{NO}_{3}^{-}\right)$, and can account for between 10 and $40 \%$ of total water column $\mathrm{NO}_{3}^{-}$uptake (Allen et al., 2005). Stable isotope probing (SIP) experiments with ${ }^{15} \mathrm{NO}_{3}^{-}$have also shown that heterotrophic bacteria in natural assemblages, including members of the Alteromonas genera, can and do take up $\mathrm{NO}_{3}^{-}$(Wawrik et al., 2012). Methods based on sorting heterotrophic and autotrophic cells with flow cytometry following ${ }^{15} \mathrm{NO}_{3}^{-}$incubation have also documented significant levels of heterotrophic bacterial $\mathrm{NO}_{3}^{-}$utilization (Bradley et al., 2010a,b,c; Lomas et al., 2011). However, the role that bacterial $\mathrm{NO}_{3}^{-}$assimilation plays in shaping microbial communities and regulating $\mathrm{NO}_{3}^{-}$flux in pelagic ecosystems remains poorly understood, though it may have important consequences for understanding the biological pump.

To gain a deeper understanding of N-related interactions between diatoms and bacteria, we developed a model coculture system using the diatom $P$. tricornutum CCMP 632 and the marine heterotrophic bacteria Alteromonas macleodii. A. macleodii represents an excellent model for investigating these interactions because Alteromonas sp. are ecologically important members of the gammaproteobacteria class, and have been shown to be amenable to genetic manipulation (Kato et al., 1998; Weyman et al., 2011). They are relatively large $(\sim 1-2$ $\mu \mathrm{m})$, rod-shaped motile bacteria that are capable of utilizing a variety of $\mathrm{C}$ and $\mathrm{N}$ sources (López-Pérez and RodríguezValera, 2014; Pedler Sherwood et al., 2015). Ecologically, they are frequently associated with nutrient and particle-rich environments and are commonly found as active and dominant members of phytoplankton-associated bacterial assemblages (Buchan et al., 2014; López-Pérez and Rodríguez-Valera, 2014). Alteromonas bacteria have previously been shown to interact with individual eukaryotic and prokaryotic phytoplankton species. These interactions range from impairing algal growth, sometimes by algicidal means (Kato et al., 1998; Mayali and Azam, 2004; 
Aharonovich and Sher, 2016) to effects that are either neutral or beneficial to algal growth in co-culture (Morris et al., 2008, 2011; Sher et al., 2011; Aharonovich and Sher, 2016). When concentrated organic matter is available, Alteromonas bacteria have been shown to be among the most rapidly dividing heterotrophic prokaryotes, and can reach high population densities (Shi et al., 2012; Pedler et al., 2014). A. macleodii, the designated type species for the Alteromonas genus, is distributed globally and is exceptionally diverse genetically (García-Martínez et al., 2002; Ivars-Martínez et al., 2008; López-Pérez et al., 2012). The strain selected for this study, A. macleodii ATCC27126, is capable of utilizing $\mathrm{NO}_{3}^{-}$as a sole $\mathrm{N}$ source in minimal (Aquil) media supplemented with a dissolved organic carbon (DOC) source, solidifying this strain as an excellent candidate for the model system employed in this study.

Through the use of targeted genetic manipulation we have gained new insights into the mechanisms governing physiological processes related to nutrient exchange and competition between diatoms and bacteria, particularly interactions involving $\mathrm{C}$ and $\mathrm{N}$. We examined model diatoms and bacteria that are both capable of $\mathrm{NO}_{3}^{-}$utilization. Leveraging new and existing genetic tools available for each organism in the model system presented here, we created both diatom and bacterial mutants lacking the ability to utilize $\mathrm{NO}_{3}^{-}$. We then examined the response of these strains in co-culture under varying $\mathrm{C}$ and $\mathrm{N}$ availability scenarios. Additionally, we conducted transcriptional profiling experiments in order to identify molecular responses of diatoms to the bacteria as well as to gain insights into the physiological status of each partner.

\section{MATERIALS AND METHODS}

\section{Strains and Culturing Conditions}

Axenic cultures of $P$. tricornutum strain CCMP 632 were obtained from the Provasoli-Guillard National Center for Culture of Marine Algae and Microbiota. Axenic cultures were confirmed via microscopy (light and DAPI staining), in addition to regular plating on marine bacterial growth media. $P$. tricornutum monocultures and A. macleodii co-cultures were grown in Aquil artificial seawater media (ASW), with modified concentrations of $\mathrm{NO}_{3}^{-}$added as sodium nitrate (Fisher Bioreagents, Waltham MA, USA) or $\mathrm{NH}_{4}^{+}$added as ammonium chloride (Fisher Bioreagents, Waltham MA, USA). Media was microwaved to $\sim 95^{\circ} \mathrm{C}$ two times prior to cooling, addition of nutrients and filter sterilization $(0.2 \mu \mathrm{m}$ bottle-top filters, Thermo Fisher Scientific, Waltham MA, USA). Experiments were conducted at $18^{\circ} \mathrm{C}$ with a light intensity of $170 \mu \mathrm{mol}$ photons $\mathrm{m}^{-2} \mathrm{~s}^{-1}$ and a $14 / 10 \mathrm{~h}$ light/dark cycle. In order to minimize variability resulting from diel effects, measurements and sampling for each experiment occurred at the same time each day, $\sim 6 \mathrm{~h}$ after light cycle onset.

A. macleodii strain ATCC27126 monocultures were grown routinely either on Zobell 2216 marine broth (MB) 1\% agar plates, or in $\mathrm{MB}$ liquid medium at $28^{\circ} \mathrm{C}$. A. macleodii growth was also supported in half-strength marine broth media, and in Aquil ASW supplemented with $5 \mathrm{mM}$ pyruvate. Liquid cultures were grown shaking at $225 \mathrm{rpm}$. Prior to co-culturing experiments, overnight cultures of $A$. macleodii culture were centrifuged at
$6000 \mathrm{x} \mathrm{g}$ for $3 \mathrm{~min}$; the supernatant was discarded, and cells were subsequently gently washed 3 times in the experimental seawater media. E. coli used for cloning was cultured in LB broth (Amresco, Solon OH, USA) or on LB agar plates at $37^{\circ} \mathrm{C}$. Antibiotic concentrations for selective bacterial growth were provided as $100 \mu \mathrm{g} / \mathrm{ml} \mathrm{Kanamycin} \mathrm{and} 100 \mu \mathrm{g} / \mathrm{ml}$ Ampicillin for A. macleodii and $50 \mu \mathrm{g} / \mathrm{ml}$ Kanamycin, $100 \mu \mathrm{g} / \mathrm{ml}$ Ampicillin, $10 \mu \mathrm{g} / \mathrm{ml}$ Chloramphenicol, $10 \mu \mathrm{g} / \mathrm{ml}$ Tetracycline, or $10 \mu \mathrm{g} / \mathrm{ml}$ Spectinomycin for E. coli as needed.

\section{Genetic Manipulation of A. macleodii and P. tricornutum}

Previous studies genetically manipulating Alteromonas bacteria focused on either undesignated species (Kato et al., 1998) or species other than A. macleodii (Weyman et al., 2011 focused on the "deep ecotype" which was reclassified as A. mediterranea), making this study the first to genetically manipulate this widespread species. The genome sequence of $A$. macleodii strain ATCC27126 was obtained from the JGI IMG data base and the DNA sequence of the single copy nasA gene was identified and used to design the knockout (KO) construct. The A. macleodii $\triangle$ nas $A$ line was engineered using SacB-mediated homologous recombination, as in Weyman et al. (2011). Gibson assembly was used to construct the suicide plasmid pRED16 (Supplementary Figure 1A), which contains an origin of replication from source plasmid pBBR1-MCS5 (incapable of replication in A. macleodii ATCC27126), an origin of transfer, a SacB gene conferring toxicity to sucrose, and $21-\mathrm{kb}$ regions homologous to the A. macleodii nas A gene flanking a kanamycin resistance cassette (Kovach et al., 1995; Gibson et al., 2009; Weyman et al., 2011). This plasmid was assembled and transformed into E. coli, which was mated overnight with the $A$. macleodii WT strain. Transconjugants were dilution-plated to obtain Kanamycin resistant single colonies, and then streaked onto 5\% sucrose plates to select for double-crossover recombinants. These were again plated to single colonies, which were screened by PCR to amplify regions specific to A. macleodii strain ATCC27126 (to confirm sole presence of this strain as the primers do not amplify in E. coli), and regions spanning both junctions of the genome insert, as well as the entire insert (data not shown). All colonies screened were identified as A. macleodii strain ATCC27126 and were positive for the KO insert. The KO phenotype (inability to utilize $\mathrm{NO}_{3}^{-}$) was confirmed by plating transconjugant colonies and the WT strain on seawater-agar plates containing pyruvate as a C source, either $\mathrm{NO}_{3}^{-}$or $\mathrm{NH}_{4}^{+}$ as a $\mathrm{N}$ source, and X-gal solution (Takara, Meadow View CA, USA) to better visualize the phenotypic effect. The WT strain was able to grow on either $\mathrm{N}$ source, while the knockout strain displayed growth on $\mathrm{NH}_{4}^{+}$but not on $\mathrm{NO}_{3}^{-}$(Supplementary Figure 1B).

P. tricornutum nitrate reductase knockout (NRKO) lines were constructed using Transcription activator-like effector nuclease (TALEN) genetic manipulation, as in Weyman et al. (2015). Using the JGI P. tricornutum genome (http://genome.jgi.doe.gov/Phatr2/Phatr2.home.html), the sequence encoding nitrate reductase (NR) (Phatr2 ID: 54983, Phatr3 ID: J54983) was identified and activity was eliminated by interrupting the sequence with a phleomycin-resistance cassette 
suitable for downstream selection. Transformation of the NRKO plasmids was accomplished by microparticle bombardment (BIO-RAD PDS-1000/He Biolistic Particle Delivery System).

\section{Experimental Design}

To address baseline physiological and transcriptional profiles of diatom and diatom-bacteria co-cultures, $1 \mathrm{~L}$ batch cultures were grown in autoclaved 2L Erlenmeyer flasks. Three treatments with three biological replicates each were examined: $P$. tricornutum monocultures, $P$. tricornutum-A. macleodii WT co-cultures, and $P$. tricornutum-A. macleodii $\triangle$ nasA co-cultures. Prior to starting the experiments, both phytoplankton and bacteria were cultured together in the relevant experimental conditions for $>7$ $P$. tricornutum generations ( $\sim 1$ week), and inoculated during $P$. tricornutum exponential phase. Sampling was conducted daily for spectrophotometric measurement of $\mathrm{NO}_{3}^{-}$, and for cell counts via flow cytometry (see below). Samples for additional physiological parameters and RNA-seq transcriptomic analysis were also collected during $P$. tricornutum exponential and stationary phase (Figure 1). Physiological parameters included in vivo fluorescence, $\mathrm{pH}, \mathrm{Chl}-\mathrm{a}, \mathrm{Fv} / \mathrm{Fm}$, and dissolved and particulate organic $\mathrm{C}$ and $\mathrm{N}$. The initial $\mathrm{NO}_{3}^{-}$concentration was $300 \mu \mathrm{M}$. Diatom specific growth rates $(\mu)$ were calculated using cell densities obtained via flow cytometry on day 2 and day 5 of the experiment. For comparison to flow cytometry results, $P$. tricornutum cells were also counted on a counting chamber and bacteria colony forming units (CFU) $\mathrm{ml}^{-1}$ were determined for the A. macleodii (see below). Every second day, the P. tricornutum monocultures were plated on $\mathrm{MB}$ and co-cultures were plated on $\mathrm{MB}$ with Kanamycin in order to confirm lack of culture cross-contamination.

Several small-scale experiments were performed to examine the effects of $\mathrm{C}$ and $\mathrm{N}$ concentration on co-culture population dynamics, interactions between bacteria and the P. tricornutum NRKO line, and $A$. macleodii growth on multiple media types. For these experiments, $20 \mathrm{ml}$ cultures and co-cultures were grown in sterile glass tubes in triplicate and $300 \mu \mathrm{L}$ samples were collected regularly and preserved with paraformaldehyde (PFA) for subsequent processing via flow cytometry (see below). Four hundred microlitre samples were also collected in order to measure $\mathrm{NO}_{3}^{-}$concentration in the DOC addition experiment (see below). A. macleodii growth on different media sources was evaluated by growing overnight cultures of $A$. macleodii WT, gently rinsing the cells two times in nutrient free Aquil ASW, and resuspending in $1 \mathrm{ml}$ of the same media prior to inoculating media treatments with 1:1000 dilution of the bacteria. Cells were grown in the following media treatments: Aquil ASW with and without $300 \mu \mathrm{M} \mathrm{NO}_{3}^{-}$(Aq and Aq- $\mathrm{N}$, respectively), $\mathrm{MB}$, and expired media from a $P$. tricornutum stationary culture filtered through a $0.2 \mu \mathrm{m}$ filter (PtF).

In DOC addition experiments, co-cultures that had been maintained semi-continuously were used for inoculations. For both the A. macleodii WT and $\triangle$ nasA-P. tricornutum co-cultures, five different DOC-addition treatments were established (each in triplicate): DOC added either at the time of inoculation (Day 0) or on days 2, 4, 6, and 8 of the experiment. A no DOC-addition

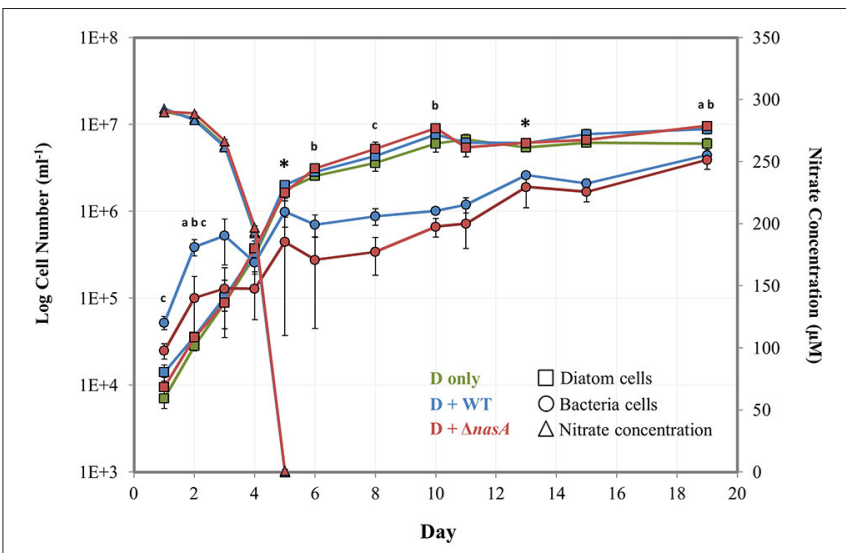

FIGURE 1 | Log number of bacteria and diatom cells (left vertical axis) determined by flow cytometry and nitrate concentrations (right vertical axis) determined by spectrophotometry during the baseline experiment. Squares $=$ diatom cell numbers, circles $=$ bacterial cell numbers, and triangles $=$ nitrate concentrations $(\mu \mathrm{M})$. Green markers $=P$. tricornutum monocultures (also noted as D only), blue markers $=P$. tricornutum-A. macleodii WT co-cultures (also noted as $\mathrm{D}+\mathrm{WT}$ ), and red markers $=P$. tricornutum-A. macleodii $\triangle$ nasA co-cultures (also noted as D $+\Delta$ nasA). Exponential growth stage was defined as days 1-6, and stationary growth phase as days 7-19. * indicates the two sampling points for physiology and transcriptomics. ${ }^{a}$ indicates that diatom cell numbers were significantly different between $P$. tricornutum monocultures and $A$. macleodii WT co-cultures. ${ }^{b}$ indicates that diatom cell numbers were significantly different between $P$. tricornutum monocultures and $A$. macleodii $\triangle$ nas $A$ co-cultures. ${ }^{C}$ indicates that bacteria cell numbers were significantly different between the $\mathrm{WT}$ and $\triangle$ nas $A$ co-cultures. All data points represent the average of $n=3$ replicates, and error bars are standard deviation. Some differences in cell numbers and nitrate concentrations (e.g., diatom monoculture nitrate concentrations, which are overlapped by the $\Delta$ nas $A$ co-culture measurements) are difficult to discern, so average non-transformed cell numbers and nitrate concentrations have been listed in Supplementary Table 2.

control was included for a total of 6 treatments. Allochthonous DOC was added as pyruvate at a concentration of $5 \mathrm{mM}$. Media contained $300 \mu \mathrm{M}$ final concentration of $\mathrm{NO}_{3}^{-}$. As a result of pyruvate interference with spectrophotometer measurement of $\mathrm{NO}_{3}^{-}$samples were sent for autoanalyzer $\mathrm{NO}_{3}^{-}$analysis (see below).

To address the impacts of varying $\mathrm{C}$ and $\mathrm{NO}_{3}^{-}$concentrations on $P$. tricornutum and A. macleodii WT population dynamics, co-cultures maintained semi-continuously from the baseline experiment were used to inoculate experiments using nine different media types. $\mathrm{NO}_{3}^{-}$concentrations of $50 \mu \mathrm{M}, 300 \mu \mathrm{M}$, and $1 \mathrm{mM}$ and DOC concentrations of $0 \mu \mathrm{M}, 50 \mu \mathrm{M}$, and $1 \mathrm{mM}$ were tested in a factorial design. Twenty milliliter cocultures were grown in sterile glass tubes in triplicate and 500 $\mu \mathrm{L}$ samples were collected for flow cytometry analysis on days 2, 4, 6, and 31. Co-cultures containing $300 \mu \mathrm{M} \mathrm{NO}_{3}^{-}$and no DOC addition were cultured semi-continuously for 5 subsequent transfers to determine steady-state growth rates of $P$. tricornutum in co-culture. To account for variability in cell concentration, $\mu$ was determined using the highest growth rate observed between any 2 subsequent sampling points in each transfer experiment. 
For the $P$. tricornutum NRKO co-culturing experiments, three different co-cultures were grown in both $\mathrm{NH}_{4}^{+}$and $\mathrm{NO}_{3}^{-}$ amended Aquil ASW; P. tricornutum NRKO only, P. tricornutum $\mathrm{NRKO}+\mathrm{WT}$ A. macleodii, and P. tricornutum $\mathrm{NRKO}+\mathrm{WT}$ A. macleodii + DOC. The P. tricornutum NRKO with and without $A$. macleodii were acclimated in $\mathrm{NH}_{4}^{+}$amended media after which they were inoculated into both media types and pyruvate was added to the relevant treatments. $\mathrm{N}$ was added as $880 \mu \mathrm{M}$ final concentration of the relevant source. Since some of the experiments included DOC amendments, we conducted an experiment to examine the impact of such DOC addition on $P$. tricornutum growth. $P$. tricornutum WT monocultures and $P$. tricornutum WT monocultures $+5 \mathrm{mM}$ pyruvate cultures were established in $20 \mathrm{ml}$ cultures as above, and run in triplicate, and media contained $880 \mu \mathrm{M}$ final concentration of $\mathrm{NO}_{3}^{-}$.

\section{Sample Collection and Processing: Cell Numbers, Physiology, and $\mathrm{NO}_{3}^{-}$Drawdown}

Cell densities of diatoms and bacteria were determined by flow cytometry, and in the case of the baseline experiment, also by manual counting methods. P. tricornutum cells were counted manually on either a Sedgwick-Rafter hemocytometer (when cell densities were low) or an Improved-Neubauer hemocytometer (IN-Cyto, Chungnam-do, Korea). A. macleodii CFU were determined by dilution-plating onto $\mathrm{MB}$ agar plates. (Both WT and $\triangle$ nas $A$ lines of $A$. macleodii were also plated on MB kanamycin plates to confirm the sole presence of $\triangle$ nasA lines. Samples for staining and cell counting via flow cytometry were preserved by adding PFA to a final concentration of $0.5 \%$. Samples were incubated at $4^{\circ} \mathrm{C}$ prior to flash freezing and storage at $-80^{\circ} \mathrm{C}$ until processing. Flow cytometry analysis was conducted on a BD FACS Aria II using the Bacteria Kit for flow cytometry (Thermo Fisher Scientific, Waltham MA, USA) for quantifying the number of diatom and bacteria cells in each sample. After the addition of beads to samples, SYBR green I DNA stain was added, effectively staining all three populations (diatoms, bacteria, and beads). Bacterial and diatom populations were quantified simultaneously, and typical flow cytometer settings were forward scatter $(F S C)=200$, side scatter $(\mathrm{SSC})=250$, FSC PMT $=550$, SYBR Green $($ SYBR Grn $)=530$, Yellow fluorescence (YFP) $=335$, with the following thresholds: $\mathrm{SSC}=200, \mathrm{FSC}=200$.

Nitrate levels were measured either via spectrophotometer or autoanalyzer (in DOC addition experiments). For spectrophotometric measurement, samples were prepared by centrifuging whole sample in Eppendorf tubes at $8000 \mathrm{~g}$ for $10 \mathrm{~min}$. Supernatant was then recovered, and stored at $-20^{\circ} \mathrm{C}$ until processing. $\mathrm{NO}_{3}^{-}$values were determined by generating a standard curve using dilutions of $880 \mu \mathrm{M} \mathrm{NO} \mathrm{NO}_{3}^{-}$media, using only curves with $>99 \%$ precision (Collos et al., 1999; Johnson and Coletti, 2002). Samples were then measured in triplicate. As allochthonous DOC addition interfered with the spectrophotometric readings, $\mathrm{NO}_{3}^{-}$and $\mathrm{NO}_{2}^{-}$analysis for DOC addition experiments was conducted using a Lachat QuikChem 8500 autoanalyzer as in Parsons et al. (1984).
Concentrations of total and dissolved organic $\mathrm{C}$ and $\mathrm{N}$ were determined using a Total Organic Carbon (TOCL) analyzer (Shimadzu) paired with an ASI-L autosampler (Shimadzu). Prior to sample collection, 24-ml glass vials were combusted at $450^{\circ} \mathrm{C}$ and vial caps were acid rinsed for $>24 \mathrm{~h}$. Five to ten milliliters samples were stored at $-20^{\circ} \mathrm{C}$ prior to dilution with milliQ and processing. Standard curves for determining $\mathrm{C}$ and $\mathrm{N}$ concentrations were generated using automated dilution and sampling of $1000 \mathrm{ppm}$ potassium hydrogen phthalate for $\mathrm{C}$, and $1000 \mathrm{ppm}$ potassium nitrate for N. Samples for determining $\mathrm{C}$ and $\mathrm{N}$ in the dissolved fraction were collected by gentle filtration through a $0.2 \mu \mathrm{m}$ syringe filter. Particulate values were determined by subtracting dissolved values from total values. Chlorophyll A (Chl a) concentrations were measured by $90 \%$ acetone extraction. Ten milliliters of the sample was gently filtered onto GF/F filters, flash frozen in in liquid $\mathrm{N}_{2}$, and stored at $-20^{\circ} \mathrm{C}$ before overnight acetone extraction and measurement on a 10AU fluorometer (Turner). Culture Fv/Fm was measured using a pam-fluorometer (WALZ). $\mathrm{pH}$ was measured using an InLab Expert $\mathrm{pH}$ probe (Mettler Toledo), calibrated using 4, 7, and $10 \mathrm{pH}$ standards (Orion Application Solutions).

\section{Sample Collection and Processing: Transcriptomics}

Transcriptomics samples were collected by gentle filtration onto $47 \mathrm{~mm} 0.2 \mathrm{um}$ polycarbonate filters (Whatmann), followed by flash freezing in liquid $\mathrm{N}_{2}$ and storage at $-80^{\circ} \mathrm{C}$ prior to processing. Total RNA was isolated using Trizol reagent (Thermo Fisher Scientific, Waltham MA, USA). The TURBO DNA-free Kit (Thermo Fisher Scientific, Waltham MA, USA) was used to digest genomic DNA. RNA was subsequently purified further using the Agencourt RNAClean XP kit (Beckman Coulter, Carlsbad CA, USA). The quality of RNA was evaluated using an Agilent 2100 Bioanalyzer (also used for subsequent quality analyses). Ribosomal RNA was removed using RiboZero Magnetic kits (Epicentre, San Diego CA, USA) with a modification of the removal solution, using a mixture of the plant, bacterial, and human/mouse/rat Removal Solutions in a ratio of $2: 1: 1$. Following mRNA enrichment via rRNA removal, RNA quality was further inspected via bioanalyzer. The Ovation RNA-Seq System V2 (NuGEN Technologies, Inc.) was used for first and second strand cDNA synthesis and amplification, followed by evaluation of cDNA quality via bioanalyzer. cDNA was sheared using the S2/E210 focused-ultrasonicator (Covaris) with a target size of $300 \mathrm{bp}$, confirmed by bioanalyzer. Libraries for sequencing were constructed using the Ovation ${ }^{\circledR}$ Ultralow System V2 (NuGEN Technologies, Inc.), and the quality of libraries verified by bioanalyzer prior to sequencing. Libraries were quantified using $\mathrm{qPCR}$ and a Library Quantification Kit (Kapa Biosystems), prior to sequencing on an Illumina NextSEQ500 DNA sequencer.

Paired Illumina reads were filtered for Illumina primer contamination and quality trimmed to Phred score 33 and a minimum length of 30 prior to read mapping. Reads were mapped to target genome contigs of $P$. tricornutum (http://genome.jgi.doe.gov/Phatr2/Phatr2.home.html) and 
A. macleodii ATCC 27126 using BWA MEM alignment ( $\mathrm{Li}$, 2013). Raw read counts were calculated for each gene using featureCounts (Liao et al., 2014) based on gene models for A. macleodii (CP003841) and P. tricornutum (Phatr3, http:// protists.ensembl.org/Phaeodactylum_tricornutum/Info/Index). Additional gene level de novo functional annotation was generated for $P$. tricornutum via KEGG, KO, KOG, Pfam, and TIGRfam assignments. RPKMs were computed using library mapped reads and lengths of CDS for each gene. Biological triplets were used to quantitatively estimate differential expression using edgeR (Robinson et al., 2010) to assign normalized fold-change and Benjamini-Hochberg adjusted $p$-values for each gene. Raw read counts for each gene were used in all edgeR analyses. Sequencing data generated as part of this study has been deposited at NCBI.

\section{Statistical Analyses}

In the baseline experiment, statistical analyses were conducted to examine potential differences in diatom cell numbers between the monoculture and co-culture treatments, bacteria cell numbers between co-culture treatments, and to explore whether any physiological parameters were different between treatments during the exponential or stationary phase. One-way ANOVAs were performed followed by Tukey HSD post-hoc tests. Statistical significance was assumed at $p \leq 0.05$. All statistical analyses were conducted using $\mathrm{R}$ (version 2.14.2), and were performed on raw data (i.e., not transformed).

\section{RESULTS}

\section{Baseline Physiology and Transcriptomics in Diatom-Bacteria Co-Cultures}

A baseline experiment was conducted initially to examine cell growth, culture physiology, $\mathrm{N}$ drawdown, and diatom gene expression in diatom-bacteria co-cultures. In this experiment, $\mathrm{N}$ was provided as $\mathrm{NO}_{3}^{-}$and no DOC was added. Cell counts obtained via flow cytometry were used to examine population dynamics of $P$. tricornutum and the A. macleodii strains in co-culture, which were compared to manual cell counts. Diatom growth stages for this experiment were defined generally as exponential (Day 1-5) and stationary (Day 6-19). The presence of WT or $\triangle$ nas A A. macleodii in P. tricornutum cultures did not significantly affect growth rate (Supplementary Table 1). Maximum diatom cell densities were typically similar among treatments during diatom exponential phase, but were higher in bacteria-containing cultures during stationary phase (Figure 1, Supplementary Table 2). These differences were significant between $P$. tricornutum monocultures and the A. macleodii $\triangle$ nasA co-cultures on day $2(p<0.01)$, day $6(p<0.05)$, day $10(p<0.05)$, and day $19(p<$ 0.01 ), and between $P$. tricornutum monocultures and the $A$. macleodii WT line on day $1(p<0.05)$, day $2(p<0.005)$, and day 19 ( $p<0.05$; Figure 1). Although the maximum $P$. tricornutum cell densities estimated with manual counts were slightly lower than those calculated via flow cytometry, cell counts obtained from the two methods were similar (Supplementary Figure 2).
Both A. macleodii strains were able to grow in co-culture with $P$. tricornutum, as indicated by a gradual increase in cell abundance following $P$. tricornutum exponential stage (Figure 1). This growth increase did not occur when $A$. macleodii was grown in Aquil ASW in the absence of $P$. tricornutum (Supplementary Figure 3). The A. macleodii WT strain maintained higher numbers than the $\Delta$ nas $A$ line, though patterns of growth were similar for both strains (Figure 1). These differences were significant $(p<0.05)$ on days 1,2 , and 8 of the experiment. After an initial increase in bacterial cell number in both bacteria co-culture treatments, bacterial numbers either declined (WT) or plateaued ( $\triangle$ nas $A$ ) during the P. tricornutum exponential phase (Figure 1). Subsequently, cell numbers of both strains increased during the diatom stationary phase beginning on day 5. Manual CFU counts of the bacteria showed generally the same pattern of growth, however the growth decrease during $P$. tricornutum exponential phase was more dramatic and overall CFU ml $\mathrm{ml}^{-1}$ were lower following this phase in the experiment (Supplementary Figure 2). This difference in cell counts due to methodology has been observed in prior studies (Singleton et al., 1982; Mouriño-Pérez et al., 2003), where CFU counts were lower than direct counts under low DOC conditions. Likely the CFU counts reflect only viable, culturable cells while flow cytometry counts represent all cells including dormant, active, and recently dead cells. Neither A. macleodii strain was observed to physically attach to $P$. tricornutum at any point of the P. tricornutum growth cycle (qualitative observation, data not shown).

Nitrate concentrations decreased rapidly as P. tricornutum cell concentrations increased, and were undetectable by day 5 in all treatments (Figure 1). P. tricornutum cell numbers continued to increase exponentially even after the complete depletion of $\mathrm{NO}_{3}^{-}$in the media (Figure 1). $\mathrm{NO}_{3}^{-}$drawdown was similar among treatments with and without bacteria. Samples for cell physiology that were collected during the diatom exponential (Day 5) and stationary phase (Day 13), including Chl-a, $\mathrm{pH}$, and $\mathrm{Fv} / \mathrm{Fm}$, showed no significant differences between treatments (Supplementary Table 3). Organic C and $\mathrm{N}$ were also evaluated for both the dissolved and the particulate culture fractions, and no significant differences between the treatments were observed (Supplementary Table 3).

\section{Baseline Transcriptomic Analysis}

Whole-genome transcriptome analyses were conducted at exponential (Day 5) and stationary (Day 13) sampling points. In general, a very low percentage of sequenced and mapped reads were associated with the $A$. macleodii genome, with slightly more observed in the diatom stationary samples than in the exponential samples (Table 1). The large majority of sequenced reads (>98\% in all co-culture treatments) mapped to the $P$. tricornutum genome (Table 1). As a result, analyses of $A$. macleodii gene expression are not included in this study. Genes were considered to be significantly differentially expressed (DE) when the adjusted $p<0.05$, and only genes with differential expression of $>0.75$ fold are discussed. All data reported in this paper are deposited in the NCBI sequence read archive (BioProject accession no. PRJNA319251; BioSample accession nos. SAMN04884450- SAMN04884467). 


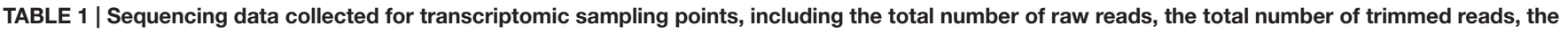

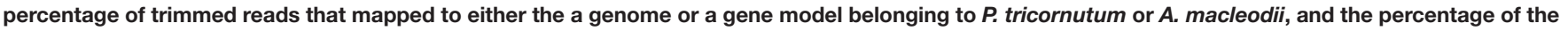
total mapped reads that corresponded to the $A$. macleodii and $P$. tricornutum genomes.

\begin{tabular}{|c|c|c|c|c|c|c|}
\hline & Raw Reads & Trimmed Reads & $\begin{array}{c}\% \text { Reads mapped to a } \\
\text { genome }\end{array}$ & $\begin{array}{c}\% \text { Reads mapped to a } \\
\text { gene model }\end{array}$ & $\begin{array}{l}\% \text { Mapped reads: } \\
\text { A. macleodii }\end{array}$ & $\begin{array}{l}\text { \% Mapped reads: } \\
\text { P. tricornutum }\end{array}$ \\
\hline \multicolumn{7}{|c|}{ EXPONENTIAL SAMPLING POINT } \\
\hline P. tricornutum Only & $1.0 \mathrm{E}+07$ & $9.9 \mathrm{E}+06$ & 84.18 & 58.29 & 0.00 & 100.00 \\
\hline P. tricornutum + A. macleodii WT & $7.7 \mathrm{E}+06$ & $7.6 \mathrm{E}+06$ & 80.74 & 35.78 & 0.21 & 99.79 \\
\hline $\begin{array}{l}\text { P. tricornutum }+A . \text { macleodii } \\
\Delta \text { nasA }\end{array}$ & $9.2 E+06$ & $9.0 E+06$ & 82.78 & 36.60 & 0.28 & 99.72 \\
\hline TOTAL & $2.7 \mathrm{E}+07$ & $2.7 \mathrm{E}+07$ & & & & \\
\hline \multicolumn{7}{|l|}{ STATIONARY SAMPLING POINT } \\
\hline P. tricornutum Only & $2.9 \mathrm{E}+07$ & $2.8 \mathrm{E}+07$ & 88.16 & 43.52 & 0.00 & 100.00 \\
\hline P. tricornutum + A. macleodii WT & $3.7 \mathrm{E}+07$ & $3.6 \mathrm{E}+07$ & 88.61 & 43.96 & 1.70 & 98.30 \\
\hline $\begin{array}{l}P . \text { tricornutum }+A . \text { macleodii } \\
\Delta \text { nas } A\end{array}$ & $3.0 \mathrm{E}+07$ & $3.0 \mathrm{E}+07$ & 88.92 & 33.69 & 1.90 & 98.10 \\
\hline TOTAL & $9.5 \mathrm{E}+07$ & $9.4 \mathrm{E}+07$ & & & & \\
\hline
\end{tabular}

No $P$. tricornutum genes were significantly differentially expressed (DE) between any of the treatment during the diatom exponential sampling point, however, during the stationary sampling point many genes were differentially expressed between the $P$. tricornutum monoculture and either or both of the $P$. tricornutum-bacteria co-cultures. A set of 34 genes were significantly DE between axenic cultures and both bacterial cocultures (Figure 2). The gene most highly upregulated in $P$. tricornutum in response to the bacteria ( $>5.9$ fold in both cocultures) is a putative voltage-gated ion channel (Phatr2 ID: 49093, Phatr3 ID: 302957 ) that has been shown to be involved in $\mathrm{NO}_{3}^{-}$sensing and transport (see discussion). Other upregulated genes include a putative ferredoxin-dependent bilin reductase (Phatr2 ID: 33770, Phatr3 ID: 303606), and a putative fatty acid desaturase (Phatr2 ID: 46830, Phatr3 ID: 306355). Several of the genes that were downregulated in $P$. tricornutum in response to bacteria were related to cellular information storage and processing such as transcriptional regulation and replication, including two different putative heat shock protein transcription factors. The two genes most highly downregulated in the presence of bacteria were a short chain dehydrogenase (Phatr2 ID: 13001, Phatr3 ID: 306282), which was downregulated 8.8 and 6.5-fold in the $\triangle$ nas $A$ and WT co-cultures, respectively, and a fatty acid hydroxylase (Phatr2 ID: N/A, Phatr3 ID: 308140), which was downregulated 5.7 and 3.9 -fold in the $\triangle$ nas $A$ and WT co-cultures, respectively (Figure 2).

Several transcripts were either upregulated or downregulated in both co-cultures, but the difference was only significant for one of the co-cultures. An additional 9 genes were DE between $P$. tricornutum monocultures and the P. tricornutumA. macleodii WT co-culture treatments (Supplementary Table 4). These include a putative $\mathrm{NO}_{2}^{-}$transporter (Phatr2 ID: 13076, Phatr3 ID: 308281), and a putative membrane associated $\mathrm{NO}_{3}^{-}$transporter (Phatr2 ID: 26029, Phatr3 ID: 307720), which exhibited a $>2.5$-fold difference. Both of these putative genes were upregulated in the $P$. tricornutum monoculture compared to the co-cultures, and had a larger expression change in the WT bacteria co-culture than the $\triangle$ nas A co-culture (Supplementary Table 4). There were 99 genes significantly DE in P. tricornutum monocultures compared to $P$. tricornutum-A. macleodii $\Delta$ nas $A$ co-cultures (Supplementary Table 4), including upregulation of a putative glutamine synthetase gene (Phatr2 ID: 51092, Phatr3 ID: 306624), a putative tryptophan/tyrosine permease (Phatr2 ID: 45852, Phatr3 ID: 310088), and a putative ferredoxin nitrite reductase (Phatr2 ID: 12902, Phatr3 ID: 308097). A putative sugar transporter (Phatr3 ID: 49722, Phatr2 ID: 311238) was downregulated in diatom monocultures, as well as additional heat shock transcription factors, including one that was downregulated >19-fold (Phatr2 ID: 48554, Phatr3 ID: 304737).

We also identified and compared expression of genes related to $\mathrm{NH}_{4}^{+}$utilization and transport. 17 putative genes were identified (Supplementary Table 5), and none were significantly DE between any treatments at a given sampling point.

\section{Growth Physiology of A. macleodii in Multiple Media Types}

In all media types, $A$. macleodii WT showed a rapid increase in cell number between inoculation on day 1 and the next measured time-point on day 3 (Supplementary Figure 3). Following this initial increase, cell numbers either decreased in all aquil-based media (Aq, Aq-N, and PtF media), or experienced a modest decrease followed by little change (MB media) (Supplementary Figure 3 ). The highest cell density occurred when cells were

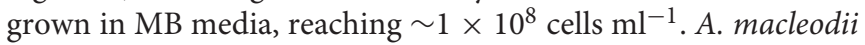
$\mathrm{WT}$ in $\mathrm{PtF}$ media reached a higher maximum cell density $(2.2 \times$ $10^{6}$ cells ml $\left.{ }^{-1}\right)$ than the Aq and Aq-N treatments $\left(8.6 \times 10^{5}\right.$ and $8.9 \times 10^{5}$ cells $\mathrm{ml}^{-1}$, respectively). 


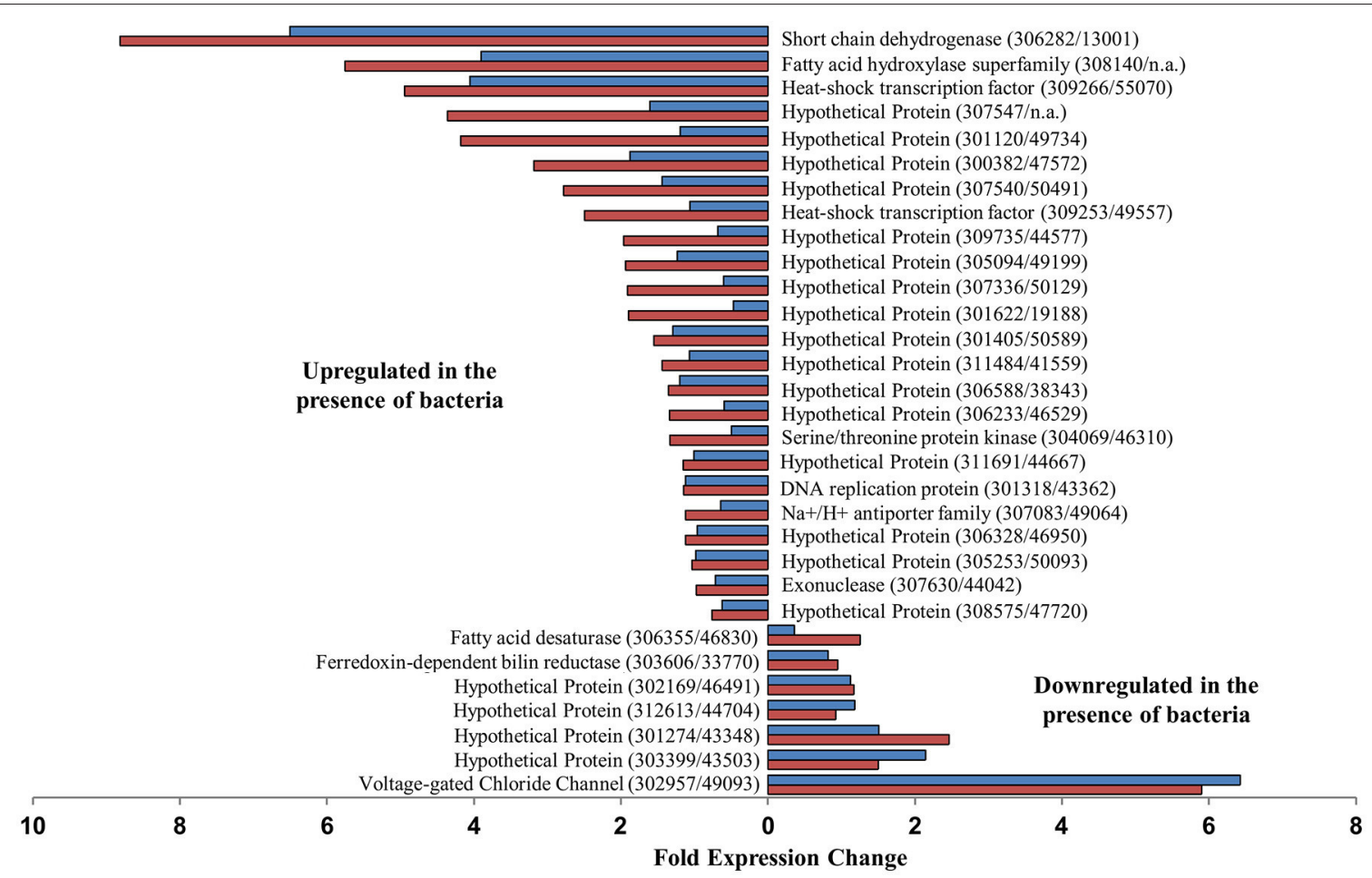

FIGURE 2 | Putative $P$. tricornutum genes that were significantly differentially expressed between $P$. tricornutum monocultures and both WT and $\Delta$ nas $\boldsymbol{A}$ bacterial co-cultures, and fold expression change. Blue bars $=\mathrm{DE}$ in WT co-cultures, red bars $=\mathrm{DE}$ in $\Delta$ nas $A$ co-cultures. Gene descriptions are adjacent to relevant data bars, with gene IDs displayed as (Phatr3 ID/Phatr2 ID).

\section{Competition between Diatoms and Bacteria for $\mathrm{NO}_{3}^{-}$}

We examined whether bacteria could impede diatom growth by competing for $\mathrm{NO}_{3}^{-}$if sufficient DOC was present for bacterial growth. We hypothesized that the presence of DOC prior to $\mathrm{NO}_{3}^{-}$ depletion could enable bacterial competition for $\mathrm{NO}_{3}^{-}$, but that competition would not occur if (1) DOC is not sufficient for bacterial growth, or (2) bacteria are unable to utilize the $\mathrm{NO}_{3}^{-}$ in the media. We tested this by culturing the diatoms with WT bacteria capable of utilizing $\mathrm{NO}_{3}^{-}$and $\triangle$ nas $A$ bacteria unable to utilize $\mathrm{NO}_{3}^{-}$as a $\mathrm{N}$ source. We then added DOC at multiple time-points and included a no DOC addition control to better understand any competitive interactions observed, measuring diatom and bacteria growth and $\mathrm{NO}_{3}^{-}$in the media (indicative of biological $\mathrm{NO}_{3}^{-}$drawdown). In co-cultures containing $\Delta$ nas $A$ bacteria, diatom growth and $\mathrm{NO}_{3}^{-}$drawdown were similar in all treatments regardless of whether and when DOC was added (Figures 3B,D,F). Numbers of $\triangle$ nas $A$ bacteria increased slightly when DOC was added prior to the depletion of $\mathrm{NO}_{3}^{-}$from the media, but were not affected when DOC was added on days after $\mathrm{NO}_{3}^{-}$depletion. In co-cultures containing diatoms and WT bacteria, when DOC was added early in the experiment (Day $\mathrm{T}_{\mathrm{o}}$ or Day 2), bacteria cell numbers increased dramatically and diatom cell numbers reached lower maximum cell densities (Figures 3A,C). Diatom cell numbers with DOC added on Day $\mathrm{T}_{\mathrm{o}}$ were $>6$ times lower than in the no DOC addition control. Media $\mathrm{NO}_{3}^{-}$was also depleted earlier in these cultures (Figures 3E,F), indicating a relationship between bacterial growth, $\mathrm{NO}_{3}^{-}$drawdown, and diatom growth impairment. When DOC was added on later time points (Day 4,6, and 8), diatom growth and $\mathrm{NO}_{3}^{-}$drawdown were similar to the no DOC addition control. Bacteria growth increased slightly when DOC was added on Day 4, but DOC addition on subsequent days had no effect.

P. tricornutum cultures with and without the addition of pyruvate (final concentration $5 \mathrm{mM}$, as used in other DOC addition experiments) did not differ significantly in cell numbers as measured at 3 different time points (Supplementary Figure 4). Cell numbers were determined on days 4,7 , and 15 of the experiment.

\section{Population Dynamics of NRKO Diatoms and WT Bacteria in Co-Culture}

We explored whether bacteria can provide diatoms with a useable $\mathrm{N}$ source and potentially "rescue" N-starved diatoms. To do this, we cultured the NRKO diatom strain (lacking the ability to use $\mathrm{NO}_{3}^{-}$) in media containing either $\mathrm{NH}_{4}^{+}$or $\mathrm{NO}_{3}^{-}$as the sole $\mathrm{N}$ source, in the presence of absence WT $A$. macleodii, and with the bacteria and a DOC addition at $\mathrm{T}_{\mathrm{O}}$ (Figure 4). The NRKO diatom was able to grow in all treatments with $\mathrm{NH}_{4}^{+}$as the provided $\mathrm{N}$ source, and in the absence of added DOC grew similarly with and without the addition of $A$. macleodii (Figures 4A,B). In $\mathrm{NH}_{4}^{+}$ media amended with DOC, bacteria numbers were much higher, and NRKO diatom cell densities were lower (Figures 4C,D), an observation similar to the DOC addition experiment described 


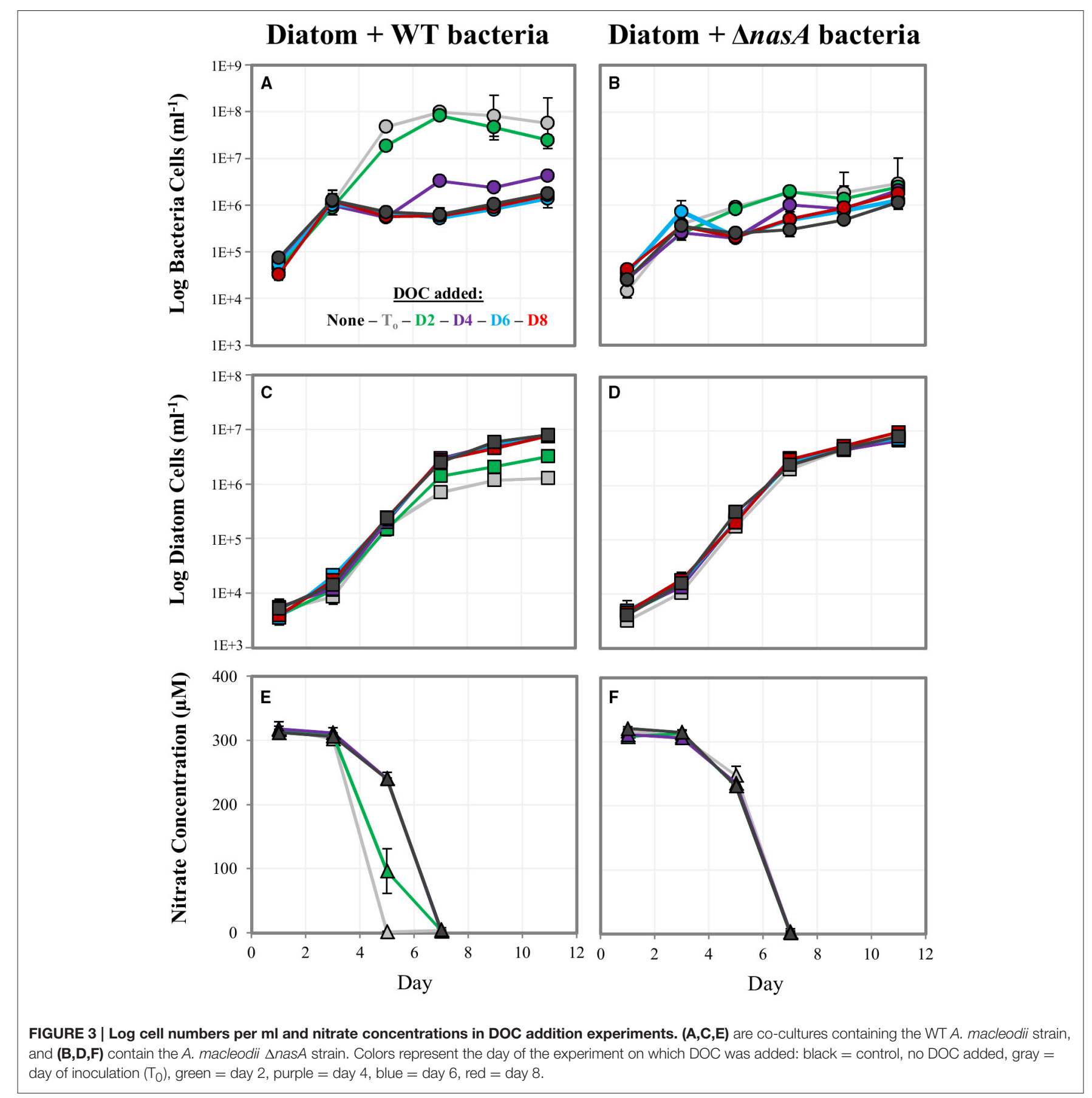

above. With $\mathrm{NO}_{3}^{-}$as the sole $\mathrm{N}$ source and without DOC addition, the diatom NRKO strains displayed little detectable growth with and without $A$. macleodii addition. However, the NRKO diatom-WT bacteria co-culture to which DOC was added displayed a much different growth response; diatom density increased linearly $\left(R^{2}=0.96\right)$ throughout the experiment, with a

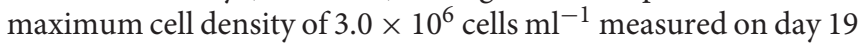
of the experiment (Figures 4A,B). Bacterial cell densities in this treatment peaked on day 9 of the experiment, and subsequently declined.

\section{Effect of Various $\mathrm{NO}_{3}^{-}$and DOC Concentrations on Diatom-Bacteria Population Dynamics}

To better understand the influence of $\mathrm{N}$ and $\mathrm{C}$ concentration on diatom-bacteria growth dynamics, we conducted a factorial experiment in which diatom-WT bacteria co-cultures were grown in 9 different media types encompassing a range of $\mathrm{NO}_{3}^{-}$ and DOC levels. In general, higher $\mathrm{NO}_{3}^{-}$levels resulted in higher numbers of both diatoms and bacteria. DOC concentrations 

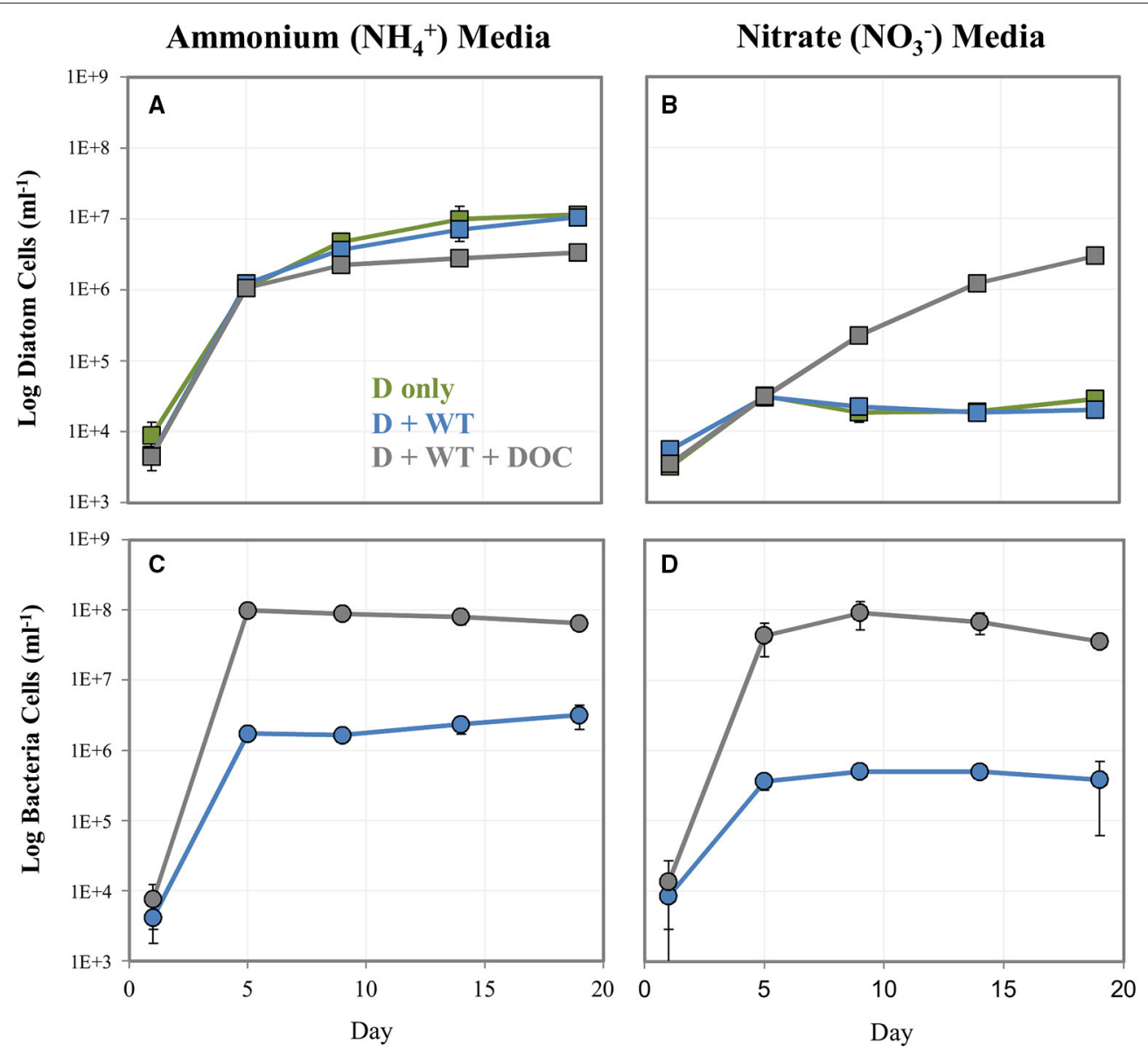

FIGURE 4 | Log cell numbers per $\mathrm{ml}$ of $P$. tricornutum NRKO $(\mathrm{A}, \mathrm{B})$ and $A$. macleodii WT bacteria (C,D) in co-culture, grown on $\mathrm{NH}_{4}^{+}$or $\mathrm{NO}_{3}^{-}$and as the sole nitrogen source. Green markers $=P$. tricornutum NRKO monoculture (also noted as D only), blue $=P$. tricornutum NRKO $+A$. macleodii WT (also noted as $\mathrm{D}+\mathrm{WT}$ ), and gray $=P$. tricornutum $\mathrm{NRKO}+\mathrm{A}$. macleodii $\mathrm{WT}+\mathrm{DOC}$ (also noted as $\mathrm{D}+\mathrm{WT}+\mathrm{DOC}$ ).

had a strong effect on bacterial cell numbers, but less of an effect on diatom concentrations except for at low $\mathrm{NO}_{3}^{-}$. At the lowest $\mathrm{NO}_{3}^{-}$concentration tested $(50 \mu \mathrm{M})$, diatom cell numbers decreased with increasing DOC concentration (Figure 5A) while bacterial cell numbers increased (Figure 5D). However, both diatom and bacteria concentrations were low at low $\mathrm{NO}_{3}^{-}$level regardless of DOC concentration compared to the higher $\mathrm{NO}_{3}^{-}$ treatments. At the higher $\mathrm{NO}_{3}^{-}$levels $(300 \mu \mathrm{M}$ and $1 \mathrm{mM})$, $P$. tricornutum concentrations were higher and similar to each other across DOC treatments (Figures 5B,C). In almost all treatments, $A$. macleodii concentrations were higher during the $P$. tricornutum exponential phase compared to the stationary sampling point on day 31 (Figures 5D-F). The reverse was true with the diatoms; cell numbers increased between day 6 and day 31 (Figures 5A-C). Final A. macleodii cell densities measured on day 31 were positively correlated with both $\mathrm{DOC}$ and $\mathrm{NO}_{3}^{-}$ concentration: lower concentrations were observed at the lower levels of both $\mathrm{NO}_{3}^{-}(50$ and $300 \mu \mathrm{M})$ and DOC $(0$ and $50 \mu \mathrm{M})$, and highest concentrations were observed in the high $\mathrm{NO}_{3}^{-}$, high DOC cultures and (Figures 5D-F).
In media containing $300 \mu \mathrm{M} \mathrm{NO}-$ and no DOC addition (the same conditions as the baseline experiment), P. tricornutum maintained in semi-continuous cultures displayed consistent growth rates across 5 rounds of culture transfer, indicating steady-state growth. The average $\mu=1.42$, with a range of $\mu=1.25$ to 1.62 (Supplementary Table 6).

\section{DISCUSSION}

\section{A Continuum: Diatom-Bacteria $\mathrm{NO}_{3}^{-}$ Utilization and the Role of Organic DOC Availability}

Since phytoplankton and bacteria often co-occur in the same environments, the concept of competition for nutrients has been of interest for decades (Bratbak and Thingstad, 1985; Thingstad et al., 1993; Logan et al., 1995; Grossart and Simon, 2007; Amin et al., 2012). New relationships between phytoplankton and bacteria are being discovered and investigated with increasing frequency (Durham et al., 2014; Amin et al., 2015; Bertrand et al., 2015; Smriga et al., 2016), in part due to recent methodological 


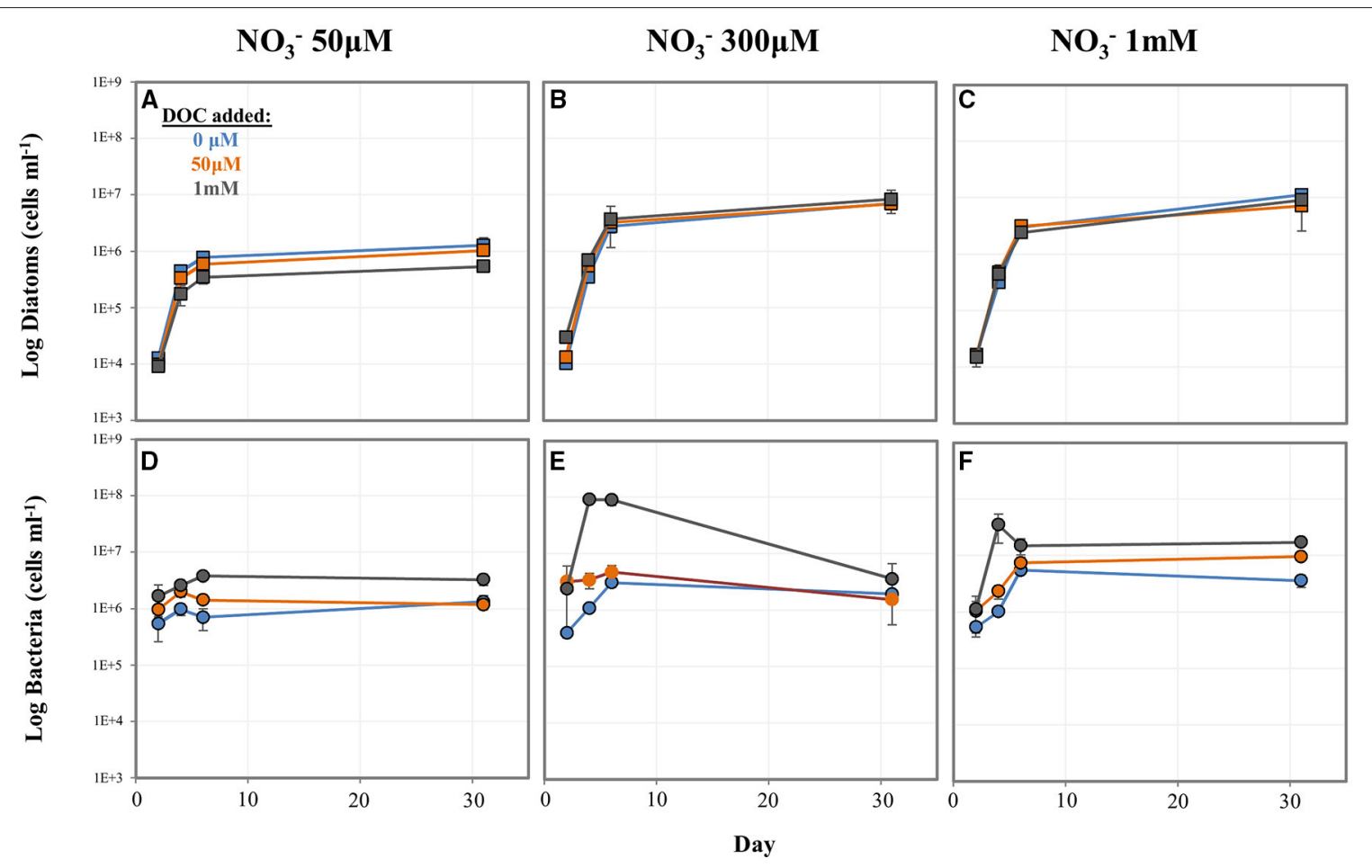

FIGURE 5 | Log cell numbers per $\mathrm{ml}$ of $\boldsymbol{P}$. tricornutum and $\boldsymbol{A}$. macleodii grown in co-culture under variable nitrate and dissolved organic carbon (DoC) concentrations. Diatom cell numbers are shown in (A-C) and bacterial numbers shown in (D-F). Blue =0 $\mu \mathrm{M}$ DOC added, orange $=50 \mu \mathrm{M}$ DOC added, and gray $=1 \mathrm{mM}$ DOC added.

advances. In particular, Alteromonas bacteria have been shown to have positive, negative, and seemingly neutral relationships with individual phytoplankton species. It is unclear, however, what role competition for nutrients may play in these observed interactions Understanding the heterogeneous landscape in which these interactions occur and the resulting impacts on global biogeochemical cycles, particularly carbon and nitrogen cycling, is an active area of research (Stocker, 2012; Worden et al., 2015; Smriga et al., 2016).

Many phytoplankton-bacteria interactions likely fall somewhere along a commensal-competitive continuum. Phytoplankton release increasing amounts of organic matter when nutrients become limited, stimulating the growth of bacteria which may compete with them for the same limiting nutrients, an apparent paradox (Bratbak and Thingstad, 1985; Bertrand et al., 2015). Studies examining acquisition of inorganic phosphate have found that bacteria can compete with phytoplankton, and that this potential competition can be nutrient concentration dependent (Bratbak and Thingstad, 1985; Thingstad et al., 1993), and bacteria-phytoplankton population dynamics may be dependent on what species are present as well as nutrient concentrations (Puddu et al., 2003; Grossart and Simon, 2007). Interestingly, while inorganic $\mathrm{N}$ availability is also a major driver in ocean productivity and biogeochemical cycling, and both phytoplankton and many bacteria can utilize it, few studies have examined these potentially important interactions (Dugdale and Goering, 1967; Allen et al., 2001; Amin et al., 2012; Jiang et al., 2015). This is despite findings that bacterial nas $A$ genes are common, diverse, and highly expressed during phytoplankton blooms, especially for particular bacterial classes and genera (including Alteromonas) (Allen et al., 2012; Jiang et al., 2015). Recent advancements in microbiology, including genetic manipulation and the introduction of powerful next generation sequencing technology, call for an examination of these relationships with an aim to understand the underlying complex cellular mechanisms.

Utilizing both WT and $\triangle$ nas $A$ bacteria in co-culture with diatoms presents the opportunity to explore how the bacteria and diatom in this model system impact one another and are impacted by $\mathrm{NO}_{3}^{-}$availability and utilization. $\mathrm{NO}_{3}^{-}$was drawn down quickly in the experiments, and the diatom population continued to increase in all co-cultures even after the complete depletion of $\mathrm{NO}_{3}^{-}$from the media, which is consistent with reports of the ability of diatoms to rapidly accumulate and store $\mathrm{N}$ present in the environment (Cermeño et al., 2011). During exponential phase with no DOC added to the system, $P$. tricornutum growth rate, cell number, and other aspects of $P$. tricornutum physiology, including growth rate, Chl a concentration, $\mathrm{Fv} / \mathrm{Fm}$, and culture $\mathrm{pH}$ were not affected by the presence of either bacterial strain (Figure 1, Supplementary Figure 2, Supplementary Tables 1, 3). At this sampling point, bacterial numbers began to increase after an initial decrease in the experiment. One possible explanation for these observations is that during the exponential phase, the diatom and bacteria co-exist in a commensal relationship whereby the diatom is not affected by the presence of bacteria, but the bacteria are able to 
benefit from diatom organic matter. However, it is also possible that low bacterial cell numbers and biomass obscure any positive or negative effect that the bacteria may be having on the diatoms on a smaller scale, and as a result differences are not observable based on the methods we used in this study. Later in the diatom's stationary phase, when nitrogen is limited, cultures containing bacteria reached higher cell densities than the $P$. tricornutum monocultures while bacterial numbers also continued to increase, suggesting a potential cooperative relationship. We hypothesize that the increase in diatom cell number is the result of bacteria providing diatoms with a viable nitrogen source in exchange for DOC (discussed further below).

Previous studies have examined growth effects of Alteromonas bacteria in co-culture with phytoplankton. Alteromonas bacteria species cultured with eukaryotic phytoplankton have been shown to exhibit algicidal (thought to be the result of secreted dissolved substances) and non-algicidal effects (reviewed in Mayali and Azam, 2004). When cultured with the prokaryotic cyanobacteria from the Prochlorococcus genus, the presence of Alteromonas sometimes provide the algae with benefits by protecting them from oxidative stress (Morris et al., 2008, 2011) while in other cases they can cause growth inhibition (Sher et al., 2011; Aharonovich and Sher, 2016). In prior non-Alteromonas coculturing studies, dynamics between phytoplankton and bacteria have been shown to manifest late in the growth cycle (Grossart and Simon, 2007; Wang et al., 2014), though often the result is commensal bacteria turning algicidal, possibly to relieve nutrient stress. Immediate growth increases in diatom populations before and during exponential phase resulting from the presence of bacteria have also been observed (Grossart and Simon, 2007; Amin et al., 2015). These results are for the most part different from what we observed in our study, which may be due to the differences in the species of both phytoplankton and bacteria examined (even within the genus Alteromonas, species are quite diverse and were not always identified in these studies). Despite being observed in a prokaryote-prokaryote co-culturing system, the possibility that Alteromonas bacteria may protect phytoplankton from oxidative stress is interesting and could be examined in the future using the model system developed in this study.

While the presence of the bacteria alone did not hinder diatom growth, when DOC was added early in the diatom growth phase (prior to the depletion of $\mathrm{NO}_{3}^{-}$from the media) the bacteria could acquire $\mathrm{NO}_{3}^{-}$from the media, making it unavailable to the diatoms. Our data suggest that depending on the availability of allochthonous DOC, bacteria that have the ability to utilize $\mathrm{NO}_{3}^{-}$in the environment are able to effectively compete for $\mathrm{NO}_{3}^{-}$. This pattern was not observed in co-cultures containing $\triangle$ nas A bacteria, illustrating how bacteria that are unable to use $\mathrm{NO}_{3}^{-}$cannot take advantage of surplus organic $\mathrm{C}$ in $\mathrm{NO}_{3}^{-}$ cultures, and in the case of $\triangle$ nas $A$ appear to be limited by diatom $\mathrm{C}$ production. The WT bacteria generally maintained higher cell numbers than the $\triangle$ nas $A$ bacteria, possibly suggesting that the WT bacteria were limited by $\mathrm{C}$ while the $\triangle$ nas $A$ bacteria were limited by $\mathrm{N}$. However, the addition of DOC to $\triangle$ nas $A$ bacteria co-cultures did result in a slight bacterial growth increase (Figure 3B). Thus, it is possible that a co-limitation scenario may also arise in low concentrations of both bioavailable $\mathrm{N}$ and $\mathrm{C}$.
When diatoms interact with bacteria that can utilize $\mathrm{NO}_{3}^{-}$, the concentration of both $\mathrm{NO}_{3}^{-}$and DOC present may impact their dynamics in complex ways. To explore this, we tested the effects of various $\mathrm{NO}_{3}^{-}$and DOC levels on population dynamics of $P$. tricornutum-A. macleodii co-cultures. We observed that $P$. tricornutum cell densities were largely regulated by $\mathrm{NO}_{3}^{-}$ concentrations rather than DOC level or bacteria cell densities. An exception was at a low $\mathrm{NO}_{3}^{-}$concentrations $(50 \mu \mathrm{M})$, where bacterial accumulation of $\mathrm{NO}_{3}^{-}$linked to increased bacteria cell numbers appeared to reduce diatom growth and final cell densities. This trend was not observed in the higher $\mathrm{NO}_{3}^{-}$ treatments, where diatom cell densities were similar between $50 \mu \mathrm{M}$ and $1 \mathrm{mM}$ DOC concentrations despite an increase in bacteria cell density. This suggests that at low $\mathrm{NO}_{3}^{-}$levels, bacterial growth made possible by DOC availability can have a negative effect on diatom cell numbers. Based on a similar pattern observed in the DOC addition study discussed above, where $\mathrm{NO}_{3}^{-}$drawdown was correlated with high bacterial and low diatom cell numbers in high DOC conditions, we hypothesize that in this experiment fast bacterial acquisition of $\mathrm{NO}_{3}^{-}$in the media made $\mathrm{NO}_{3}^{-}$limiting for diatom growth. At higher $\mathrm{NO}_{3}^{-}$concentrations this effect was not observed, which could be explained by the diatoms having sufficient opportunity to acquire and store $\mathrm{N}$ since more was available. The diatoms may also be able to utilize nitrogen derived from dead or growtharrested bacteria during stationary phase. This is supported by the observation that bacterial abundance peaked during the exponential phase of $P$. tricornutum regardless of $\mathrm{NO}_{3}^{-}$level or DOC addition and subsequently declined, with the exception of the $1 \mathrm{mM} \mathrm{NO}_{3}^{-} / 50 \mu \mathrm{M}$ DOC treatment.

Bacterial cell numbers were strongly affected by DOC concentration. Without the addition of DOC, bacterial cell densities generally increased with increasing $\mathrm{NO}_{3}^{-}$and corresponding increases in diatom cell density. This likely reflects the link between diatom population and DOC availability; higher diatom density as a result of higher $\mathrm{N}$ concentrations leads to higher total DOC available for bacteria utilization. It is also possible that changes in DOC composition may affect bacterial growth dynamics. At higher DOC concentrations, bacteria could utilize $\mathrm{NO}_{3}^{-}$in the media to reach higher cell densities than with ambient DOC alone, a result consistent with other DOC addition experiments conducted in this study. By late stationary phase (Day 31), bacteria cell densities were variable. This may be the result of complex $\mathrm{N}$ and $\mathrm{C}$ recycling dynamics following initial uptake by bacteria and diatoms, and further studies may help to elucidate how cellular responses of diatoms and bacteria lead to the population changes we observed.

\section{Exchange of Nitrogen Substrates between Diatoms and Bacteria}

Our findings suggest that the diatoms and bacteria in our model system are able to exchange nitrogen substrates with each other. A large portion of $\mathrm{N}$ consumed by phytoplankton is ultimately released as dissolved organic nitrogen (DON) in oceanic, coastal, and estuarine environments (Wheeler and Kirchman, 1986; Bronk et al., 1994; Berman and Bronk, 2003), and is a valuable source of $\mathrm{N}$ for marine bacteria. Previous studies on P. tricornutum have shown that both organic $\mathrm{C}$ and $\mathrm{N}$ are 
released by $P$. tricornutum, and that concentrations increase after the cells enter stationary phase (Chen and Wangersky, 1996; Pujo-Pay et al., 1997). The bacteria in the present study were able to survive and grow in co-culture with the diatom using diatom-derived organic $\mathrm{C}$, and bacteria concentrations increased after the onset of diatom stationary phase, which is consistent with utilization of diatom derived organic matter. We further observed that the $\triangle$ nasA bacteria strain in co-culture grew despite the inability to use $\mathrm{NO}_{3}^{-}$, which was the only $\mathrm{N}$ source provided in the ASW media. This leaves diatom-derived $\mathrm{N}$ as the most plausible source for bacterial growth.

While the paradigm for phytoplankton-bacteria relationships is typically that of bacteria utilizing phytoplankton-derived organic matter, and in some cases exchanging various substrates to facilitate this acquisition, few studies have examined if and how diatoms may use bacterial-derived N. Given the high rate of bacterial turnover in the ocean, this could potentially represent an important $\mathrm{N}$ source, especially under $\mathrm{N}$ limiting conditions. Diatoms are known to utilize a variety of organic and inorganic N substrates (Bronk et al., 1994, 2006; Waser et al., 1998). One recent study suggests that bacteria may use $\mathrm{NH}_{4}^{+}$as a diatom signaling molecule (Amin et al., 2015). Our results show that the NRKO diatom lines could survive and grow normally in $\mathrm{NH}_{4}^{+}$but not $\mathrm{NO}_{3}^{-}$. The addition of $A$. macleodii to the diatom cultures without a coincident DOC media amendment resulted in low bacterial cell numbers and did not increase NRKO diatom cell numbers, suggesting that either the bacteria do not provide the diatom with useable $\mathrm{N}$ substrates in this physiological state, or that the amount supplied is not sufficient for diatom growth. Potentially, the bacteria could provide the diatoms with useable $\mathrm{N}$, but the amount produced by the low cell numbers observed was not enough to detect diatom population recovery using our methods. Our study does not address other possible interactions at the cellular level (e.g., metabolic shifts perhaps observable using metabolomics or transcriptomics), which may clarify whether $\mathrm{N}$ is being provided by bacteria in this co-culture. When DOC was added to the NRKO co-cultures in $\mathrm{NO}_{3}^{-}$media, both bacteria and diatom growth increased substantially. This strongly suggests that the bacteria supply the diatoms with a $\mathrm{N}$ substrate, perhaps made possible by the large bacterial numbers resulting from the DOC addition, followed by nitrogen release upon the onset of carbon-limited stationary phase. Alternatively or concurrently, after reaching maximum cell density early in the experiment the bacteria may subsequently die allowing $P$. tricornutum to recycle some of the organic $\mathrm{N}$ from the dead bacterial cells. Some bacteria were detected in the P. tricornutum NRKO cultures without the addition of $A$. macleodii. The addition of DOC to A. macleodii amended cultures resulted in high bacterial densities similar to what was observed in the $P$. tricornutum WT-A. macleodii co-cultures (Figure 3), thus we believe $A$. macleodii growth was responsible for the observed increase in $P$. tricornutum NRKO cell numbers. Even if this is not the case (i.e., the growth of other bacteria present contributed to the high bacterial cell numbers), our results strongly suggest that the high abundance of bacteria due to DOC addition was linked to diatom recovery, and our study presents a proof of concept that diatoms can utilize bacterial-derived N. Though the scope of this study does not directly address the specific bacterial $\mathrm{N}$ source, the transcriptomic analysis conducted during the baseline experiment elucidates $\mathrm{N}$-related diatom cellular pathways that may be influenced by bacteria, such as those involved in $\mathrm{NO}_{3}^{-}$ and $\mathrm{NH}_{4}^{+}$acquisition and metabolism.

\section{Further Insights into "Bacterial Responsive" Genes Revealed by RNA-seq}

Using RNA-seq, we were able to identify several putative $P$. tricornutum genes that were responsive to the presence of bacteria, some of which suggest N-related interactions. A recent study examined the response of two Prochlorococcus strains in co-culture with $A$. macleodii bacteria, and they also found that several algal genes were bacterial-responsive (Aharonovich and Sher, 2016). The study examines prokaryotic rather than eukaryotic gene expression, and is thus difficult to compare. However, it demonstrates the value of transcriptome analyses in developing hypotheses about microbial interactions and, along with our study, lays the framework for a robust analysis of interactions involving $A$. macleodii bacteria with both prokaryotic and eukaryotic algae in a model laboratory system.

All differential gene expression in our study was observed in the stationary samples, long after $\mathrm{NO}_{3}^{-}$had been depleted from the media (Figure 1), and cells were potentially $\mathrm{N}$ stressed. One discernable pattern is related to downregulation of multiple $\mathrm{N}$ transporters $\left(\mathrm{NO}_{2}^{-}\right.$and $\left.\mathrm{NO}_{3}^{-}\right)$in diatom cultures containing bacteria (Figure 2, Supplementary Table 4). One of these transporters (Phatr2ID: 49093, Phatr3 ID: 302957) was one of the mostly highly significantly DE putative genes identified in the data set. Orthologs of this ion transporter in Arabidopsis has been shown to bind to and sense $\mathrm{NO}_{3}^{-}$(Huang et al., 1996; Liu et al., 1999), suggesting a possible role in diatom $\mathrm{NO}_{3}^{-}$ acquisition. Inorganic $\mathrm{N}$ transporters including those $\mathrm{DE}$ in our dataset are commonly upregulated during nitrogen stress conditions (Levitan et al., 2014; Alipanah et al., 2015; JGI genome annotation, Allen, 2006). Downregulation in cultures containing bacteria suggests that bacteria are contributing to alleviation of diatom $\mathrm{N}$ stress, which is further supported by the higher diatom cell numbers observed in co-cultures during stationary phase and also our finding that under certain $\mathrm{N}$ stress conditions (i.e., high DOC present) bacteria have the ability to provide diatoms with $\mathrm{N}$ in forms other than $\mathrm{NO}_{3}^{-}$. In Levitan et al. (2014), expression of glutamine synthetase II (GSII) followed a similar expression pattern of downregulation under $\mathrm{N}$-stress, and we also observed significant downregulation of this gene in bacteria-containing co-cultures. Another gene related to diatom N metabolism, ornithine cyclodeaminase (Phatr2: 54222, Phatr3: 305662), is involved in the diatom Urea cycle and was downregulated compared to P. tricornutum monocultures (Allen et al., 2011). While these two genes were only significantly DE between the $P$. tricornutum monoculture and the $\triangle$ nas $A$ bacterial co-cultures (Supplementary Table 4), they were downregulated in both cocultures indicating a common bacterial-responsive pattern.

Some $\mathrm{NH}_{4}^{+}$transporters have also been shown to be upregulated during $\mathrm{N}$ stress, while others are downregulated or unaffected (Levitan et al., 2014; Alipanah et al., 2015). 
Examination of $\mathrm{NH}_{4}^{+}$acquisition and transport genes in our dataset did not reveal any significant DE between $P$. tricornutum monocultures and co-cultures (Supplementary Table 5). In Amin et al. (2015), it was suggested that bacteria provide $\mathrm{NH}_{4}^{+}$to diatoms as a signaling molecule, which was partially supported by the upregulation of $\mathrm{NH}_{4}^{+}$transport genes in bacteria, as well as an increase in $\mathrm{NH}_{4}^{+}$measured in co-cultures. However, $\mathrm{NH}_{4}^{+}$ transport genes were not DE in the diatom they examined, which may suggest that the cellular impacts of this potential exchange are not apparent at the transcriptional level in diatoms.

Several other bacterial responsive genes, including the many unannotated hypothetical proteins in our dataset, may be interesting candidates for further investigation. Several heat shock transcription factors were upregulated in diatom-bacteria co-cultures compared to monocultures. These are transcriptional regulators of heat shock proteins involved in cellular stress responses (Sorger, 1991). High expression may indicate a stress response caused by the bacteria, however, little is known about the regulation of this complex pathway in diatoms, and many non-transcriptional steps are involved in heat shock protein expression and regulation (Sorger, 1991). Upregulation of other putative genes in co-cultures may play a role in exchange of important metabolites or intracellular signaling pathways. These include a putative sugar transporter (Phatr2 ID: 49722, Phatr3 ID: 311238) which was $>2$ fold upregulated in $P$. tricornutum in both co-cultures (Supplementary Table 4), and the two putative genes that were most highly upregulated and significantly DE in both co-cultures: a putative short chain dehydrogenase (Phatr2 ID: 13001, Phatr3 ID: 306282) and a putative fatty acid hydroxylase (Phatr3 ID: 308140). Short chain dehydrogenases in particular have been shown to serve as molecular links between nutrient signaling and plant hormone biosynthesis in Arabidopsis (Cheng, 2002). Further analysis using our model system may allow determination of the role of such genes in diatom-bacteria interactions.

Using the genetically tractable model system developed in this study, we have described mechanisms of interaction between diatoms and bacteria that may be of global biogeochemical significance. Our data strongly suggests bidirectional exchange of $\mathrm{N}$ substrates between diatoms and bacteria, and revealed

\section{REFERENCES}

Aharonovich, D., and Sher, D. (2016). Transcriptional response of Prochlorococcus to co-culture with a marine Alteromonas: differences between strains and the involvement of putative infochemicals. ISME J. doi: 10.1038/ ismej.2016.70. [Epub ahead of print].

Alipanah, L., Rohloff, J., Winge, P., Bones, A. M., and Brembu, T. (2015). Whole-cell response to nitrogen deprivation in the diatom Phaeodactylum tricornutum. J. Exp. Bot. 66, 6281-6296. doi: 10.1093/jxb/ erv340

Allen, A. E. (2006). Transcript annotation: JGI Genome Portal Phaeodactylum tricornutum. Available online at: http://genome.jgi.doe.gov/annotator/servlet/ jgi.annotation.Annotation?pDb=Phatr2\&pStateVar=View\&pProteinId $=$ 26029\&pViewType $=$ protein\&pDummy $=699949276669001$ (Accessed March 15, 2016).

Allen, A. E., Booth, M. G., Frischer, M. E., Verity, P. G., Zehr, J. P., and Zani, S. (2001). Diversity and detection of nitrate assimilation genes in marine bacteria. putative diatom genes and pathways that may be impacted by the presence of bacteria and involved in $\mathrm{N}$ exchange. Furthermore, we have demonstrated that under certain environmental conditions (i.e., high DOC), marine bacteria are able to effectively compete with diatoms for $\mathrm{NO}_{3}^{-}$, which may influence predictions of primary productivity and nutrient utilization by phytoplankton in the ocean and associated estimates of $\mathrm{C}$ export via the biological pump.

\section{AUTHOR CONTRIBUTIONS}

$\mathrm{RD}$ and $\mathrm{AA}$ designed research; $\mathrm{RD}, \mathrm{SS}$, and $\mathrm{HZ}$ performed research; RD, SS, and JM analyzed data; and RD and AA wrote the paper.

\section{FUNDING}

Funding was provided to AA by the Gordon and Betty Moore Foundation (GBMF3828 and GBMF5006), the US Department of Energy (DE-SC0008593) and the National Science Foundation (OCE-1136477). Funding was provided to RD by the UCSD/SIO Center for Marine Biodiversity and Conservation.

\section{ACKNOWLEDGMENTS}

We would like to acknowledge the following people for their contributions to this research project: Phillip Weyman for assistance with $A$. macleodii culturing and genetic engineering, Erin Bertrand for assistance with co-culturing techniques, Chris Dupont for assisting with organic carbon and nitrogen analysis, Mark Novotny for flow cytometry assistance, and Flip McCarthy for helping with data interpretation and engineering the $P$. tricornutum NRKO line. We would also like to thank Karen Beeri for sequencing assistance.

\section{SUPPLEMENTARY MATERIAL}

The Supplementary Material for this article can be found online at: http://journal.frontiersin.org/article/10.3389/fmicb. 2016.00880
Appl. Environ. Microbiol. 67, 5343-5348. doi: 10.1128/AEM.67.11.53435348.2001

Allen, A. E., Booth, M. G., Verity, P. G., and Frischer, M. E. (2005). Influence of nitrate availability on the distribution and abundance of heterotrophic bacterial nitrate assimilation genes in the Barents Sea during summer. Aquat. Microb. Ecol. 39, 247-255. doi: 10.3354/ame039247

Allen, A. E., Dupont, C. L., Oborník, M., Horák, A., Nunes-Nesi, A., McCrow, J. P., et al. (2011). Evolution and metabolic significance of the urea cycle in photosynthetic diatoms. Nature 473, 203-207. doi: 10.1038/nature10074

Allen, A. E., Laroche, J., Maheswari, U., Lommer, M., Schauer, N., Lopez, P. J., et al. (2008). Whole-cell response of the pennate diatom Phaeodactylum tricornutum to iron starvation. Proc. Natl. Acad. Sci. U.S.A. 105, 10438-10443. doi: 10.1073/pnas.0711370105

Allen, A. E., Vardi, A., and Bowler, C. (2006). An ecological and evolutionary context for integrated nitrogen metabolism and related signaling pathways in marine diatoms. Curr. Opin. Plant Biol. 9, 264-273. doi: 10.1016/j.pbi.2006.03.013 
Allen, L. Z., Allen, E. E., Badger, J. H., McCrow, J. P., Paulsen, I. T., Elbourne, L. D., et al. (2012). Influence of nutrients and currents on the genomic composition of microbes across an upwelling mosaic. ISME J. 6, 1403-1414. doi: 10.1038/ismej.2011.201

Amin, S. A., Hmelo, L. R., van Tol, H. M., Durham, B. P., Carlson, L. T., Heal, K. R., et al. (2015). Interaction and signalling between a cosmopolitan phytoplankton and associated bacteria. Nature 522, 98-101. doi: 10.1038/nature14488

Amin, S. A., Parker, M. S., and Armbrust, E. V. (2012). Interactions between diatoms and bacteria. Microbiol. Mol. Biol. Rev. 76, 667-684. doi: 10.1128/MMBR.00007-12

Azam, F., and Malfatti, F. (2007). Microbial structuring of marine ecosystems. Nat. Rev. Microbiol. 5, 782-791. doi: 10.1038/nrmicro1747

Bell, W., and Mitchell, R. (1972). Chemotactic and growth responses of marine bacteria to algal extracellular products. Biol. Bull. 143, 265-277. doi: $10.2307 / 1540052$

Berman, T., and Bronk, D. a. (2003). Dissolved organic nitrogen: a dynamic participant in aquatic ecosystems. Aquat. Microb. Ecol. 31, 279-305. doi: 10.3354/ame031279

Bertrand, E. M., McCrow, J. P., Moustafa, A., Zheng, H., McQuaid, J. B., Delmont, T. O., et al. (2015). Phytoplankton-bacterial interactions mediate micronutrient colimitation at the coastal Antarctic sea ice edge. Proc. Natl. Acad. Sci. U.S.A. 112, 9938-9943. doi: 10.1073/pnas.1501615112

Bowler, C., Allen, A. E., Badger, J. H., Grimwood, J., Jabbari, K., Kuo, A., et al. (2008). The Phaeodactylum genome reveals the evolutionary history of diatom genomes. Nature 456, 239-244. doi: 10.1038/nature07410

Bradley, P. B., Lomas, M. W., and Bronk, D. A. (2010a). Inorganic and organic nitrogen use by phytoplankton along chesapeake bay, measured using a flow cytometric sorting approach. Estuaries Coasts 33, 971-984. doi: 10.1007/s12237-009-9252-y

Bradley, P. B., Sanderson, M. P., Frischer, M. E., Brofft, J., Booth, M. G., Kerkhof, L. J., et al. (2010b). Inorganic and organic nitrogen uptake by phytoplankton and heterotrophic bacteria in the stratified Mid-Atlantic Bight. Estuar. Coast. Shelf Sci. 88, 429-441. doi: 10.1016/j.ecss.2010.02.001

Bradley, P. B., Sanderson, M. P., Nejstgaard, J. C., Sazhin, A. F., Frischer, M. E., Killberg-Thoreson, L. M., et al. (2010c). Nitrogen uptake by phytoplankton and bacteria during an induced Phaeocystis pouchetii bloom, measured using size fractionation and flow cytometric sorting. Aquat. Microb. Ecol. 61, 89-104. doi: 10.3354/ame01414

Bratbak, G., and Thingstad, T. F. (1985). Phytoplankton-bacteria interactions: an apparant paradox? Analysis of a model system with both competition and commensalism. Mar. Ecol. Prog. Ser. 25, 23-30. doi: 10.3354/meps025023

Bronk, D. A., Glibert, P. M., and Ward, B. B. (1994). Nitrogen uptake, dissolved organic nitrogen release, and new production. Science 265, 1843-1846. doi: $10.1126 /$ science. 265.5180 .1843

Bronk, D. A., See, J. H., Bradley, P., and Killberg, L. (2006). DON as a source of bioavailable nitrogen for phytoplankton. Biogeosci. Discuss. 3, 1247-1277. doi: 10.5194/bgd-3-1247-2006

Buchan, A., LeCleir, G. R., Gulvik, C. A., and González, J. M. (2014). Master recyclers: features and functions of bacteria associated with phytoplankton blooms. Nat. Rev. Microbiol. 12, 686-696. doi: 10.1038/nrmicro3326

Cermeño, P., Lee, J.-B., Wyman, K., Schofield, O., and Falkowski, P. G. (2011). Competitive dynamics in two species of marine phytoplankton under non-equilibrium conditions. Mar. Ecol. Prog. Ser. 429, 19-28. doi: 10.3354/meps09088

Chen, W., and Wangersky, P. J. (1996). Production of dissolved organic carbon in phytoplankton cultures as measured by high-temperature catalytic oxidation and ultraviolet photo- oxidation methods. J. Plankton Res. 18, 1201-1211. doi: 10.1093/plankt/18.7.1201

Cheng, W.-H. (2002). A unique short-chain dehydrogenase/reductase in Arabidopsis glucose signaling and abscisic acid biosynthesis and functions. Plant Cell Online 14, 2723-2743. doi: 10.1105/tpc.006494

Collos, Y., Mornet, F., Sciandra, A., Waser, N., Larson, A., and Harrison, P. J. (1999). An optical method for the rapid measurement of micromolar concentrations of nitrate in marine phytoplankton cultures. J. Appl. Phycol. 11, 179-184. doi: 10.1023/A:1008046023487

Dortch, Q. (1990). The interaction between ammonium and nitrate uptake in phytoplankton. Mar. Ecol. Prog. Ser. 61, 183-201. doi: 10.3354/meps061183

Dugdale, R. C., and Goering, J. J. (1967). Uptake of new and regenerated forms of nitrogen in primary productivity. Limnol. Oceanogr. 12, 196-206. doi: 10.4319/lo.1967.12.2.0196
Durham, B. P., Sharma, S., Luo, H., Smith, C. B., Amin, S. A., Bender, S. J., et al (2014). Cryptic carbon and sulfur cycling between surface ocean plankton. Proc. Natl. Acad. Sci. USA. 112, 453-457. doi: 10.1073/pnas.1413137112

Falkowski, P. G., and Oliver, M. J. (2007). Mix and match: how climate selects phytoplankton. Nat. Rev. Microbiol. 5, 813-819. doi: 10.1038/nrmicro1751

Fuhrman, J. A. (1989). Dominance of bacterial biomass in the Sargasso Sea and its ecological implications. Mar. Ecol. Prog. Ser. 57, 207-217. doi: 10.3354/meps057207

García-Martínez, J., Acinas, S. G., Massana, R., and Rodríguez-Valera, F. (2002). Prevalence and microdiversity of Alteromonas macleodii-like microorganisms in different oceanic regions. Environ. Microbiol. 4, 42-50. doi: 10.1046/j.14622920.2002.00255.x

Geider, R. J., La Roche, J., Greene, R. M., and Olaizola, M. (1993). Response of the photosynthetic apparatus of Phaeodactylum tricornutum (Bacillariophycea) to nitrate, phosphate, or iron starvation. J. Phycol. 29, 755-766. doi: 10.1111/j.0022-3646.1993.00755.x

Gibson, D. G., Young, L., Chuang, R.-Y., Venter, J. C., Hutchison, C. A., and Smith, H. O. (2009). Enzymatic assembly of DNA molecules up to several hundred kilobases. Nat. Methods 6, 343-345. doi: 10.1038/nmeth.1318

Grossart, H., and Simon, M. (2007). Interactions of planktonic algae and bacteria: effects on algal growth and organic matter dynamics. Aquat. Microb. Ecol. 47, 163-176. doi: 10.3354/ame047163

Huang, N. C., Chiang, C. S., Crawford, N. M., and Tsay, Y. F. (1996). CHL1 encodes a component of the low-affinity nitrate uptake system in Arabidopsis and shows cell type-specific expression in roots. Plant Cell 8, 2183-2191. doi: $10.1105 /$ tpc.8.12.2183

Ivars-Martínez, E., D’Auria, G., Rodríguez-Valera, F., Sánchez-Porro, C., Ventosa, A., Joint, I., et al. (2008). Biogeography of the ubiquitous marine bacterium Alteromonas macleodii determined by multilocus sequence analysis. Mol. Ecol. 17, 4092-4106. doi: 10.1111/j.1365-294X.2008.03883.x

Jiang, X., Dang, H., and Jiao, N. (2015). Ubiquity and diversity of heterotrophic bacterial nasA genes in diverse marine environments. PLoS ONE 10:e0117473. doi: 10.1371 /journal.pone.0117473

Jiao, N., Herndl, G. J., Hansell, D. A., Benner, R., Kattner, G., Wilhelm, S. W., et al. (2011). The microbial carbon pump and the oceanic recalcitrant dissolved organic matter pool. Nat. Rev. Microbiol. 9, 555. doi: 10.1038/nrmicro2386-c5

Johnson, K. S., and Coletti, L. J. (2002). In situ ultraviolet spectrophotometry for high resolution and long-term monitoring of nitrate, bromide and bisulfide in the ocean. Deep. Res. Part I Oceanogr. Res. Pap. 49, 1291-1305. doi: 10.1016/S0967-0637(02)00020-1

Karas, B. J., Diner, R. E., Lefebvre, S. C., McQuaid, J., Phillips, A. P. R., Noddings, C. M., et al. (2015). Designer diatom episomes delivered by bacterial conjugation. Nat. Commun. 6:6925. doi: 10.1038/ncomms7925

Kato, J., Amie, J., Murata, Y., Kuroda, A., Mitsutani, A., and Ohtake, H. (1998). Development of a genetic transformation system for an Alga-Lysing Bacterium. Appl. Environ. Microbiol. 64, 2061-2064.

Keil, R., and Kirchman, D. (1991). Contribution of dissolved free amino acids and ammonium to the nitrogen requirements of heterotrophic bacterioplankton. Mar. Ecol. Prog. Ser. 73, 1-10. doi: 10.3354/meps073001

Kovach, M. E., Elzer, P. H., Hill, D. S., Robertson, G. T., Farris, M. A., Roop, R. M., et al. (1995). Four new derivatives of the broad-host-range cloning vector pBBR1MCS, carrying different antibiotic-resistance cassettes. Gene 166, 175-176. doi: 10.1016/0378-1119(95)00584-1

Levitan, O., Dinamarca, J., Zelzion, E., Lun, D. S., Guerra, L. T., Kim, M. K., et al. (2014). Remodeling of intermediate metabolism in the diatom Phaeodactylum tricornutum under nitrogen stress. Proc. Natl. Acad. Sci. U.S.A. 112, 412-417. doi: $10.1073 /$ pnas. 1419818112

Liao, Y., Smyth, G. K., and Shi, W. (2014). FeatureCounts: an efficient general purpose program for assigning sequence reads to genomic features. Bioinformatics 30, 923-930. doi: 10.1093/bioinformatics/btt656

$\mathrm{Li}, \mathrm{H}$. (2013). Aligning sequence reads, clone sequences and assembly contigs with BWA-MEM. arXiv: 1303.3997 [q-bio.GN].

Liu, K. H., Huang, C. Y., and Tsay, Y. F. (1999). CHL1 is a dual-affinity nitrate transporter of Arabidopsis involved in multiple phases of nitrate uptake. Plant Cell 11, 865-874. doi: 10.1105/tpc.11.5.865

Logan, B. E., Passow, U., Alldredge, A. L., Grossartt, H.-P., and Simont, M. (1995). Rapid formation and sedimentation of large aggregates is predictable from coagulation rates (half-lives) of transparent exopolymer particles (TEP). Deep Sea Res. Part II Top. Stud. Oceanogr. 42, 203-214. doi: 10.1016/09670645(95)00012-F 
Lomas, M. W., Bronk, D. A., and van den Engh, G. (2011). Use of flow cytometry to measure biogeochemical rates and processes in the ocean. Ann. Rev. Mar. Sci. 3, 537-566. doi: 10.1146/annurev-marine-120709-142834

Lomas, M. W., and Gilbert, P. M. (2000). Comparisons of nitrate uptake, storage, and reduction in marine diatoms and flagellates. J. Phycol. 36, 903-913. doi: 10.1046/j.1529-8817.2000.99029.x

López-Pérez, M., Gonzaga, A., Martin-Cuadrado, A.-B., Onyshchenko, O., Ghavidel, A., Ghai, R., et al. (2012). Genomes of surface isolates of Alteromonas macleodii: the life of a widespread marine opportunistic copiotroph. Sci. Rep. 2:696. doi: 10.1038/srep00696

López-Pérez, M., and Rodriguez-Valera, F. (2014). "The family Alteromonadaceae." in The Prokaryotes, eds E. Rosenberg, E. F. DeLong, S. Lory, E. Stackebrandt, and F. Thompson (Berlin; Heidelberg: Springer), 69-92. doi: 10.1007/978-3-642-38922-1_233

Matthijs, M., Fabris, M., Broos, S., Vyverman, W., and Goossens, A. (2015). Profiling of the early nitrogen stress response in the diatom Phaeodactylum tricornutum reveals a novel family of RING-domain transcription factors. Plant Physiol. 170, 489-498. doi: 10.1104/pp.15.01300

Mayali, X., and Azam, F. (2004). Algicidal bacteria in the sea and their impact on algal blooms. J. Eukaryot. Microbiol. 51, 139-144. doi: 10.1111/j.15507408.2004.tb00538.x

Morris, J. J., Johnson, Z. I., Szul, M. J., Keller, M., and Zinser, E. R. (2011). Dependence of the cyanobacterium Prochlorococcus on hydrogen peroxide scavenging microbes for growth at the ocean's surface. PLoS ONE 6:e16805. doi: 10.1371/journal.pone.0016805

Morris, J. J., Kirkegaard, R., Szul, M. J., Johnson, Z. I., and Zinser, E. R. (2008). Facilitation of robust growth of Prochlorococcus colonies and dilute liquid cultures by "helper" heterotrophic bacteria. Appl. Environ. Microbiol. 74, 4530-4534. doi: 10.1128/AEM.02479-07

Morrissey, J., Sutak, R., Paz-Yepes, J., Tanaka, A., Moustafa, A., Veluchamy, A., et al. (2015). A novel protein, ubiquitous in marine phytoplankton, concentrates iron at the cell surface and facilitates uptake. Curr. Biol. 25, 364-371. doi: 10.1016/j.cub.2014.12.004

Mouriño-Pérez, R. R., Worden, A. Z., and Azam, F. (2003). Growth of Vibrio cholerae $\mathrm{O} 1$ in red tide waters off California. Appl. Environ. Microbiol. 69, 6923-6931. doi: 10.1128/AEM.69.11.6923-6931.2003

Nymark, M., Sharma, A. K., Sparstad, T., Bones, A. M., and Winge, P. (2016). A CRISPR/Cas9 system adapted for gene editing in marine algae. Sci. Rep. 6:24951. doi: 10.1038/srep24951

Parsons, T. R., Maita, Y., and Lalli, C. M. (1984). A Manual of Chemical and Biological Methods for Seawater Analysis. Oxford: Pergamon.

Pedler, B. E., Aluwihare, L. I., and Azam, F. (2014). Single bacterial strain capable of significant contribution to carbon cycling in the surface ocean. Proc. Natl. Acad. Sci. U.S.A. 111, 7202-7207. doi: 10.1073/pnas.1401887111

Pedler Sherwood, B., Shaffer, E. A., Reyes, K., Longnecker, K., Aluwihare, L. I., and Azam, F. (2015). Metabolic characterization of a model heterotrophic bacterium capable of significant chemical alteration of marine dissolved organic matter. Mar. Chem. 177, 357-365. doi: 10.1016/j.marchem.2015. 06.027

Pomeroy (1974). The ocean's food web, a changing paradigm. Bioscience 24, 499-504. doi: 10.2307/1296885

Puddu, A., Zoppini, A., Fazi, S., Rosati, M., Amalfitano, S., and Magaletti, E. (2003). Bacterial uptake of DOM released from P-limited phytoplankton. FEMS Microbiol. Ecol. 46, 257-268. doi: 10.1016/S0168-6496(03)00197-1

Pujo-Pay, M., Conan, P., and Raimbault, P. (1997). Excretion of dissolved organic nitrogen by phytoplankton assessed by wet oxidation and $15 \mathrm{~N}$ tracer procedures. Mar. Ecol. Prog. Ser. 153, 99-111. doi: 10.3354/meps 153099

Robinson, M. D., McCarthy, D. J., and Smyth, G. K. (2010). edgeR: a bioconductor package for differential expression analysis of digital gene expression data. Bioinformatics 26, 139-140. doi: 10.1093/bioinformatics/ btp616

Sarmento, H., and Gasol, J. M. (2012). Use of phytoplankton-derived dissolved organic carbon by different types of bacterioplankton. Environ. Microbiol. 14, 2348-2360. doi: 10.1111/j.1462-2920.2012.02787.x

Serra, J. L., Llama, M. J., and Cadenas, E. (1978). Nitrate utilization by the diatom Skeletonema costatum: II. regulation of nitrate uptake. Plant Physiol. 62, 991-994. doi: 10.1104/pp.62.6.991
Sher, D., Thompson, J. W., Kashtan, N., Croal, L., and Chisholm, S. W. (2011). Response of Prochlorococcus ecotypes to co-culture with diverse marine bacteria. ISME J. 5, 1125- 1132. doi: 10.1038/ismej.2011.1

Shi, Y., McCarren, J., and Delong, E. F. (2012). Transcriptional responses of surface water marine microbial assemblages to deep-sea water amendment. Environ. Microbiol. 14, 191-206. doi: 10.1111/j.1462-2920.2011.02598.x

Siaut, M., Heijde, M., Mangogna, M., Montsant, A., Coesel, S., Allen, A., et al. (2007). Molecular toolbox for studying diatom biology in Phaeodactylum tricornutum. Gene 406, 23-35. doi: 10.1016/j.gene.2007.05.022

Singleton, F. L., Attwell, R., and Jangi, S. (1982). Effects of temperature and salinity on Vibrio cholerae. Appl. Environ. Microbiol. 44, 1047-1058.

Smriga, S., Fernandez, V. I., Mitchell, J. G., and Stocker, R. (2016). Chemotaxis toward phytoplankton drives organic matter partitioning among marine bacteria. Proc. Natl. Acad. Sci. U.S.A. 113, 1576-1581. doi: 10.1073/pnas.1512307113

Sorger, P. K. (1991). Heat shock factor and the heat shock response. Cell 65, 363-366. doi: 10.1016/0092-8674(91)90452-5

Stocker, R. (2012). Marine microbes see a sea of gradients. Science 338, 628-633. doi: 10.1126/science.1208929

Thingstad, T. F., Skjoldal, E. F., and Bohne, R., a (1993). Phosphorus cycling and algal bacterial competition in Sandsfjord, Western Norway. Mar. Ecol. Prog. Ser. 99, 239-259. doi: 10.3354/meps099239

Wang, H., Tomasch, J., Jarek, M., and Wagner-Dobler, I. (2014). A dual-species co-cultivation system to study the interactions between Roseobacters and dinoflagellates. Front. Microbiol. 5:311. doi: 10.3389/fmicb.2014.00311

Waser, N. A., Yu, Z., Tada, K., Paul, J., Turpin, D. H., and Calvertl, S. E. (1998). Nitrogen isotope fractionation during nitrate, ammonium and urea uptake by marine diatoms and coccolithophores under various conditions of N availability. Mar. Ecol. Prog. Ser. 169, 29-41. doi: 10.3354/meps169029

Wawrik, B., Boling, W. B., van Nostrand, J. D., Xie, J., Zhou, J., and Bronk, D. A. (2012). Assimilatory nitrate utilization by bacteria on the West Florida Shelf as determined by stable isotope probing and functional microarray analysis. FEMS Microbiol. Ecol. 79, 400-411. doi: 10.1111/j.1574-6941.2011.01226.x

Weyman, P. D., Beeri, K., Lefebvre, S. C., Rivera, J., McCarthy, J. K., Heuberger, A. L., et al. (2015). Inactivation of Phaeodactylum tricornutum urease gene using transcription activator-like effector nuclease-based targeted mutagenesis. Plant Biotechnol. J. 13, 460-470. doi: 10.1111/pbi.12254

Weyman, P. D., Smith, H. O., and Xu, Q. (2011). Genetic analysis of the Alteromonas macleodii [NiFe]-hydrogenase. FEMS Microbiol. Lett. 322, 180-187. doi: 10.1111/j.1574-6968.2011.02348.x

Wheeler, P. A., and Kirchman, D. L. (1986). Utilization of inorganic and organic nitrogen by bacteria in marine systems. Limnol. Oceanogr. 31, 998-1009. doi: 10.4319/lo.1986.31.5.0998

Whitman, W. B., Coleman, D. C., and Wiebe, W. J. (1998). Prokaryotes: the unseen majority. Proc. Natl. Acad. Sci. U.S.A. 95, 6578-6583. doi: 10.1073/pnas.95.12.6578

Worden, A. Z., Follows, M. J., Giovannoni, S. J., Wilken, S., Zimmerman, A. E., and Keeling, P. J. (2015). Rethinking the marine carbon cycle: factoring in the multifarious lifestyles of microbes. Science 347:1257594. doi: $10.1126 /$ science. 1257594

Yongmanitchai, W., and Ward, O. P. (1991). Growth of and Omega-3 fatty acid production by Phaeodactylum tricornutum under different culture conditions. Appl. Environ. Microbiol. 57, 419-425.

Zehr, J. P., and Ward, B. B. (2002). Nitrogen cycling in the ocean: new perspectives on processes and paradigms. Appl. Environ. Microbiol. 68, 1015-1024. doi: 10.1128/AEM.68.3.1015-1024.2002

Conflict of Interest Statement: The authors declare that the research was conducted in the absence of any commercial or financial relationships that could be construed as a potential conflict of interest.

Copyright $\odot 2016$ Diner, Schwenck, McCrow, Zheng and Allen. This is an openaccess article distributed under the terms of the Creative Commons Attribution License (CC BY). The use, distribution or reproduction in other forums is permitted, provided the original author(s) or licensor are credited and that the original publication in this journal is cited, in accordance with accepted academic practice. No use, distribution or reproduction is permitted which does not comply with these terms. 